\title{
東南極における海域-陸域シームレス堆積物掘削研究の展望
}

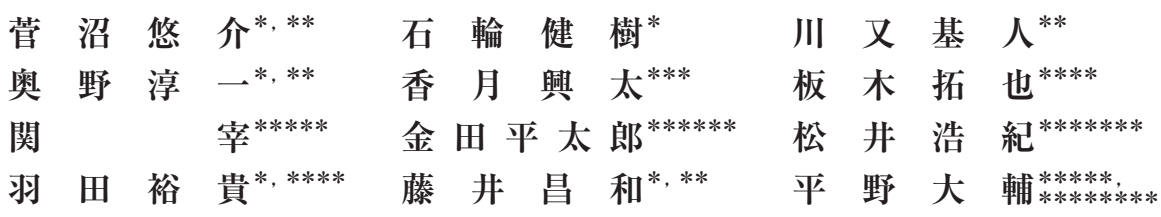

\section{Perspectives on a Seamless Marine-lake Sediment Coring Study in East Antaretica}

\author{
Yusuke SUGANUMA*,**, Takeshige ISHIWA*, Moto KAWAMATA**, \\ Jun'ichi OKUNO*,**, Kota KATSUKI***, Takuya ITAKI****, \\ Osamu SEKI $^{* * * * *}$, Heitaro KANEDA ${ }^{* * * * * *}$, Hiroki MATSUI ${ }^{* * * * * * *}$, \\ Yuki HANEDA*, ****, Masakazu FUJII ${ }^{*, * *}$ and Daisuke HIRANO ${ }_{* * * * * * * * * *}^{* * * *}$
}

[Received 19 August, 2019; Accepted 21 April, 2020]

\begin{abstract}
The Antarctic Ice Sheet (AIS) is one of the largest potential contributors to future sea-level changes. Recently, an acceleration of AIS volume loss through basal melting and iceberg calving has been reported based on several studies using satellite observations, including radar altimetry, interferometer, and gravity measurements. A recent model that couples ice sheet and climate dynamics and incorporates hydrofracturing mechanism of buttressing ice shelves predicts a higher sea-level rise scenario for the next 500 years. However, the calibration and reproducibility of the sea-level rise projection from these models relies on geological sea-level reconstructions of past warm intervals. This suggests that a highly reliable reconstruction of the past AIS is essential for evaluating its stability and anticipating its contribution to future sea-level rise. In particular, a relative sea-level reconstruction in East Antarctica is the key to solving the problems and refining future projections. The current understanding of sea-level change along the East Antarctic margin is reviewed, including Glacial Isostatic Adjustment (GIA) effects, and a

\footnotetext{
* 国立極地研究所地圈研究グループ

** 総合研究大学院大学極域科学専攻

*** 島根大学エスチュアリー研究センター

***** 産業技術総合研究所地質調査総合センター

***** 北海道大学低温科学研究所

******* 中央大学理工学部都市環境学科

******** 秋田大学大学院国際資源学研究科/高知大学海洋コア総合研究センター

********* 北海道大学北極域研究センター

* National Institute of Polar Research, Tachikawa, 190-8518, Japan

** Department of Polar Science, School of Multidisciplinary Sciences, The Graduate University for Advanced Studies (SOKENDAI), Tachikawa, 190-8518, Japan

*** Estuary Research Center, Shimane University, Matsue, 690-8504, Japan

**** Geological Survey of Japan, AIST, Tsukuba 305-8567, Japan

***** Institute of Low Temperature Science, Hokkaido University, Sapporo, 060-0819, Japan

******* Faculty of Science and Engineering, Chuo University, Tokyo, 112-8551, Japan

******* Graduate School of International Resource Sciences, Akita University, Akita, 010-8502, Japan / Center for Advanced Marine Core Research, Kochi University, Nankoku, 783-8502, Japan

******** Arctic Research Center, Hokkaido University, Sapporo, 001-0021, Japan
} 
new strategy is proposed to address this topic based on seamless sediment coring from marine to lake in the East Antarctic margin. This project will provide essential data on AIS change since the last interglacial period.

Key words : East Antarctica, Antarctic Ice Sheet (AIS), sea-level change, seamless sediment coring, Glacial Isostatic Adjustment (GIA)

キーワード：東南極，南極水床，海水準変動，シームレス堆積物掘削，水河性地殼均衡調整

\section{I. はじめに}

南極水床は，地球上の全水河・氷床体積の約 90 \%を占める巨大な淡水リザーバであり（Vaughan et $a l ., 2013)$ ，そのすべてが融解すれば全球的に 海水準を約 $58 \mathrm{~m}$ も上昇させうる (Fretwell et $a l ., 2013)$ 。また，水床縁での海洋・氷床相互作 用による南極水床の変動は, 南大洋の海水生産や 南極底層水生成をコントロールし, 海洋大循環 (熱塩循環) による地球の熱分配を通して，地球 の気候システムに大きな影響を与えている（例え ば, 勝又, 2018; 大島, 2018）（図 1 ）。一方，過去 500 万年間の地球史を振り返ると, 大気 $\mathrm{CO}_{2}$ 濃 度に対応した全球的気候変動によって南極水床も 大きく変化し, 鮮新世温暖期において全球的な海 水準変動を引き起こしてきたと考えられている（例 えば, Miller et al., 2012）（図 2 ）。このように, 南極水床は地球気候システムにおけるきわめて重 要な要素であるといえる。

近年, 衛星観測や南極沿岸の海洋・棚水上など での観測によって南極水床の融解や流出の加速が 相次いで報告され（例えば, Rignot et al., 2011, 2019; Pritchard et al., 2012; Shepherd et al., 2012, 2018; Paolo et al., 2015)，近い将来起こる とされる急激な海水準上昇が社会的に強く懸念さ れはじめた。とくに南極水床の融解過程には，一 度超えてしまうと容易に後戻りできない「Tipping point」が存在すると考えられることから（Pattyn et al., 2018), 現在その実態の理解に注目が集 まっている。気候・水床モデルシミュレーション によると，近年融解が加速している西南極水床の みならず，西南極水床より 1 桁大きな体積をも

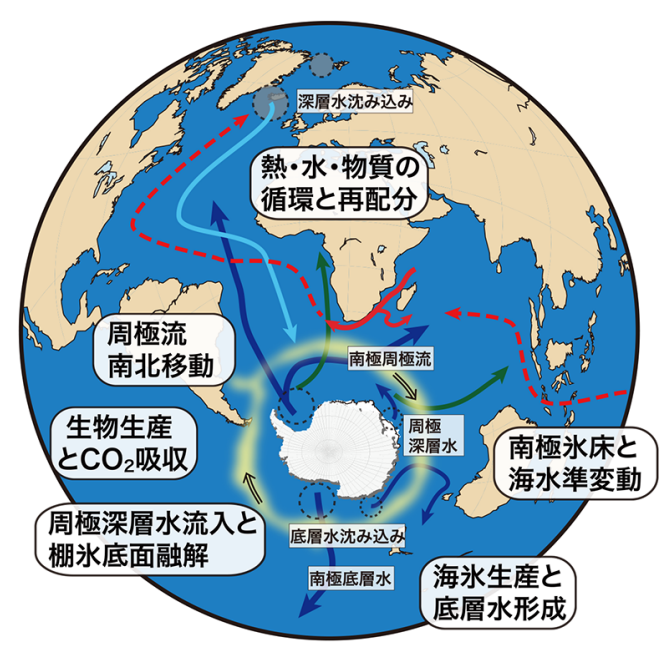

図 1 全球気候変動を駆動する南大洋 - 南極水床の概 念図. 矢印はそれぞれ表層水 (赤色), 北太西洋 深層水 (水色), 南極中層水 (緑), および南極底 層水（青色）を示す.

Fig. 1 Schematic figure showing roles of Antarctic Ice Sheet and Southern Ocean in the Earth's climatic system. Arrows represent surface water (red), North Atlantic Deep Water (light blue), Antarctic Intermediate Water (green), and Antarctic Bottom Water (blue).

つ東南極水床の一部も温暖化に敏感であり（図 $3)$ ，その融解による海水準上昇は最大で 2100 年までに $1.1 \mathrm{~m}, 2500$ 年には $15.7 \mathrm{~m}$ にも達する 可能性が指摘されている (DeConto and Pollard, 2016)。この南極水床融解予測に従うと, 全球的 な海水準上昇は従来の予測（IPCC, 2013）を遙 かに上回る。もし，このような急激かつ大規模な 海水準上昇が近未来に起きた場合，人口が集中す る都市部や食料生産を担う低地帯が水没するな 


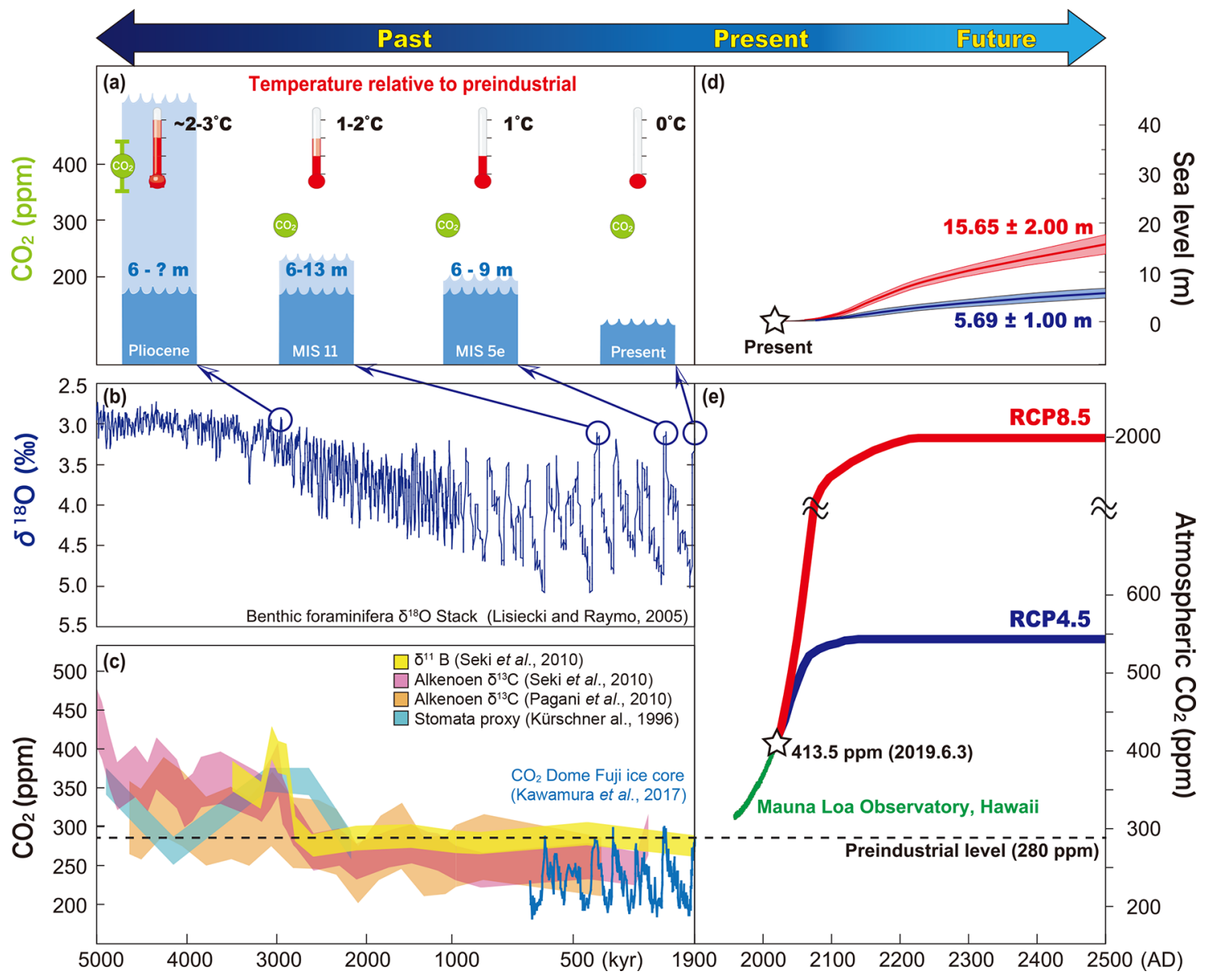

図 2 過去 500 万年間および現在から西暦 2500 年までの地球環境変動復元と将来予測. (a) 酸素同位体ステージ (marine isotope stages: MIS) 1，5e，11，および鮮新世温暖期における大気 $\mathrm{CO}_{2}$ 濃度，全球平均気温（産業革命 前との比較)，および全球平均海水準（水色は推定值の幅を示す）(Dutton et al., 2015 を改変), (b) 沉地球的な 酸素同位体比変動曲線 (Lisiecki and Raymo, 2005), (c) 各種プロキシによる大気 $\mathrm{CO}_{2}$ 濃度復元 (Kürschner et al., 1996; Pagani et al., 2010; Seki et al., 2010） およびドームふじ水床コアの大気 $\mathrm{CO}_{2}$ 濃度記録（Kawamura et $a l ., 2017)$ ，(d）異なった大気 $\mathrm{CO}_{2}$ 濃度上昇シナリオに基づく，気候・水床モデルシミュレーションによる南極 氷床融解の寄与による海水準上昇予測（DeConto and Pollard, 2016），（e） IPCC 第 5 次報告書（IPCC, 2013）に よる 2500 年までの $\mathrm{CO}_{2}$ 濃度上昇予測.

Fig. 2 Paleoclimatic record for the last five million years and projection until $2500 \mathrm{AD}$. (a) Global mean temperature (relative to preindustrial level), atmospheric $\mathrm{CO}_{2}$, global mean sea level (GMSL). Light blue shading indicates uncertainty of GMSL maximum (modified from Dutton et al., 2015) (b) LR04 benthic stack (Lisiecki and Raymo, 2005), (c) Proxy-based atmospheric $\mathrm{CO}_{2}$ reconstructions (Kürschner et al., 1996; Pagani et al., 2010; Seki et al., 2010), and a $\mathrm{CO}_{2}$ record of Dome Fuji ice core (Kawamura et al., 2017). (d) Large Ensemble model analyses of future Antarctic contributions to GMSL (DeConto and Pollard, 2016) based on different representative Carbon Pathway scenarios (RCP 4.5 and 8.5), (e) Representative Carbon Pathway scenarios up to 2500 AD (IPCC, 2013).

ど，都市計画も大きく変更せざるを得なくなるた なる。

め, 人間社会の活動基盤の維持のためにも海水準 南極水床の質量収支は，多くの山岳水河と異な 上昇予測の精度向上はきわめて重要な研究課題と り，水床表面での涵養と消耗（表面質量収支） 


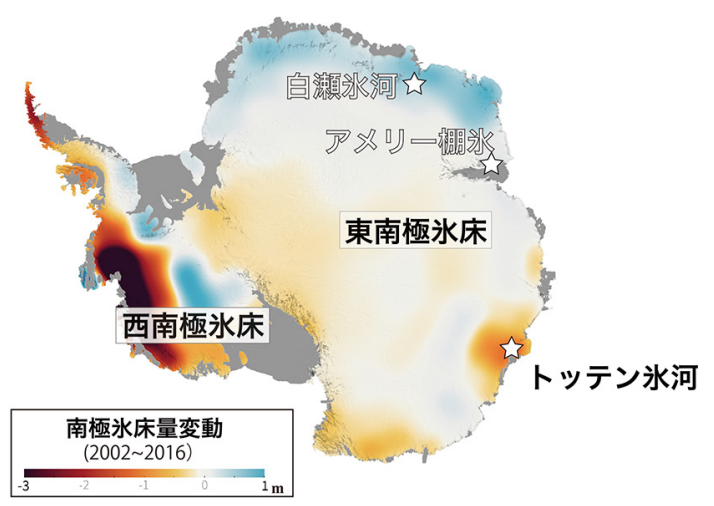

図 3 衛星重力観測 (Gravity Recovery And Climate Experiment, GRACE）に基づく2002〜2016 年 の南極水床量変動 $(\mathrm{m})$. NASA's Goddard Space Flight Center（2017）を一部改変．以前より顕著 な融解が観測されていた西南極に加えて，近年 は東南極でもトッテン氷河流域などで水床量の 減少が観測されている。

Fig. 3 Changes in ice mass of Antarctic ice sheet (m) from 2002 to 2016 based on observations using Gravity Recovery and Climate Experiment (GRACE) satellites. Modified from NASA's Goddard Space Flight Center (2017). In addition to the rapidly decreasing West Antarctic Ice Sheet, the Totten Glacier Catchment also started to show a rapid ice mass loss.
のみでなく，水床沿岸でおきる棚水の底面融解 (Basal melting) や水床からの分離（カービング： Calving，その後，海洋に浮かぶ水山となる）も 含むため，そのメカニズムの理解と定量的な観測 は容易ではない（杉山, 2018）（図 4 ）。しかし最 近の研究の進展によって，棚水の底面融解につい ては，比較的暖かい海水である周極深層水（Circumpolar Deep Water: CDW）が氷床末端下に 流入し，棚水を融かす効果が従来考えられていた よりも大きいことが明らかになってきた（例え ば, Favier et al., 2014)。実際に，西南極の比較 的暖かい海水と水床が接している地域において, 棚水の水厚が急激に減少していることが報告され (Paolo et al., 2015)，近年の南極水床の急激な質 量損失が棚水の底面融解に起因することが確認さ れた。一方，棚水のカービングについては，最近 とくに Marine Ice Cliff Instability（MICI）と呼 ばれる現象が注目を集めている（Pattyn, 2018）。 MICI は，夏期に生じる棚水表面の融解水が棚水 内部に貫入することによって，カービングが促進 されるという現象であり，南極水床のさらなる急

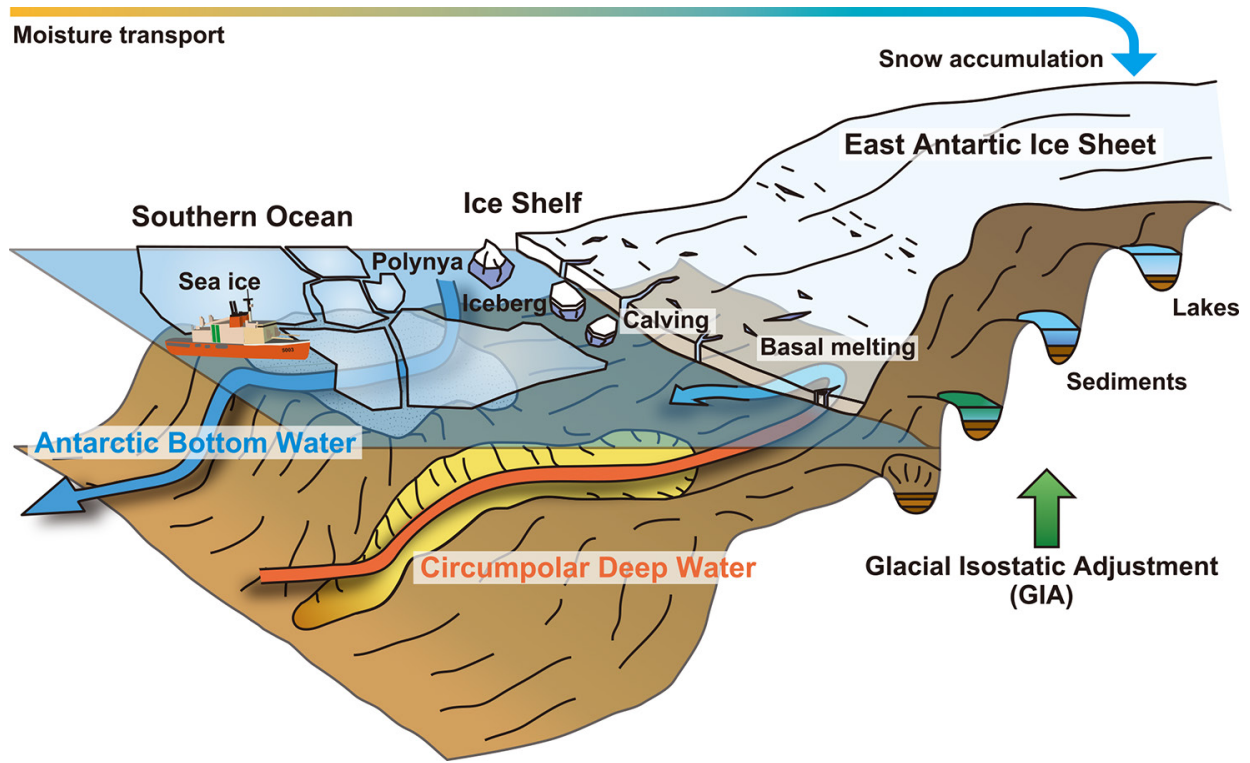

図 4 東南極沿岸における地球気候システムの重要な要素の模式図.

Fig. 4 Schematic figure showing an overview of key components of the Earth's climatic system in the East Antarctic margin. 
激な崩壊を導くとされ，一部の気候・氷床モデルシ ミュレーションにも組み込まれている（DeConto and Pollard, 2016)。しかし，いまだ直接的な MICI の観測例がないことや，これらのモデルに おいて MICI が過剩に評価されていることなどが 指摘されており（Edwards et al., 2019），南極水 床融解の将来予測に MICI を適用すべきかについ ての議論はいまだ収束していない。

このように，現在でも南極水床融解プロセスの 理解は充分に進んでいるとはいえず，最新の気候・ 水床モデルシミュレーションにおいてもその正確 な再現は難しい。一方，南極大陸やその周辺の地 形・地質学的な記録からは，断片的ではあるとは いえ，過去の南極水床変動を復元するうえで，他 の地球科学的手法では得ることができない独特の デー夕を得ることができる（三浦, 2018）。すな わち，地形・地質学的に過去の気候変動（たとえ ば海水温の変化）に対する南極水床の応答（南極 水床変動）の復元結果を，将来の気候変動の予測 に利用することである（図 2 ）。この観点から， 気候・皮床モデルを用いた将来予測のなかには, 過去の南極水床変動をモデルの制約条件（拘束 条件）としているものもある（例えば, DeConto and Pollard, 2016)。この場合，地形・地質学的 手法によって復元された過去の南極水床変動の復 元精度が，気候・氷床モデルシミュレーションに よる海水準上昇の予測精度を規定していることに なる。つまり, 南極水床変動の将来予測に対し, 地形・地質学的な手法による過去の南極水床変動 の復元精度向上が非常に重要な課題となる。

過去の南極水床変動の高精度復元を行うにあた り，南極沿岸における過去の海水準データがとく に重要となる。なぜなら海水準デー夕は，後述す るように過去の南極水床変動を直接的に反映する 地形・地質学的データだからである。しかし，南 極沿岸の海水準デー夕は現地調査の困難さなどか らきわめて限られていることもあり，推定されて いる南極水床変動史は先行研究間でばらつきが大 きく（Mackintosh et al., 2014），現在および将 来の南極水床質量収支の推定における誤差要因と なっている。つまり，将来予測の精度向上のため
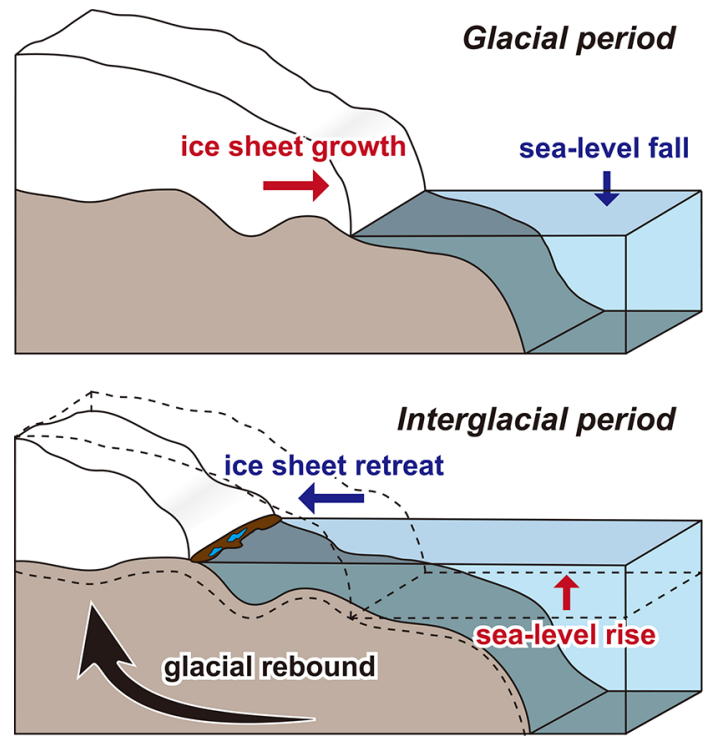

図 5 Glacial Isostatic Adjustment (GIA) の概念図. 水期と間水期の水床，海洋，おょび地殼の関係 を示す。点線と実線は，それぞれ水床融解前と 融解後の地形・海水準を表す。

Fig. 5 Schematic figure of Glacial Isostatic Adjustment (GIA). Relationships among ice sheet, ocean, and continent during glacial and interglacial periods. Dotted and solid lines correspond to geomorphology and sea level before and after the Antarctic Ice Sheet melt, respectively.

には，地形・地質学的に得られる直接的な証拠に 基づいた精度のよい南極沿岸の海水準変動デー夕 を取得し，過去の南極水床量変動とその空間分布 を復元することが鍵となる。

地形・地質学的な記録から南極水床変動を復元 する際には，氷河性地殼均衡調整（Glacial Isostatic Adjustment: GIA）を考慮する必要があ る。南極水床は，その水床自身の巨大な質量が荷 重となり，地球内部（マントル）に及ぶまで変形 をもたらす。南極水床融解は固体地球に対し荷重 解放として作用し，アイソスタシー (平衡状態) を回復しようとするために南極大陸は隆起する （例えば, Ivins and James 2005）（図 5 ）。した がって，南極大陸沿岸で観測される海水準は，水 床融解水の海洋流入による全球的な海水準変動の 効果と，観測地点周辺 $\left(100 \sim 1000 \mathrm{~km}^{2}\right.$ スケー 
ル程度）の氷床融解（荷重解放）による隆起，つ まり GIAの影響をともに受けるため, 地域ごと に異なることが予想される。この GIAを数值的 に再現する GIA モデルは，1980 年代終盤より開 発が進んでおり（例えば, Nakada and Lambeck, 1987), 氷床の融解史と地球内部の粘性構造が重 要な入力となっている。つまり, 南極大陸沿岸の 複数地点において地形・地質学的なデータに基づ き海水準変動を復元することによって, 既存の GIA モデルの入力となる水床融解史 (本論では これを GIA 融解モデルと呼ぶ）の較正や, 最適 な GIA 融解モデルを導くことも可能となる。さ らに，地形・地質学的なデー夕を基にした GIA モデルシミュレーションから, 南極水床変動量と 融解開始年代を空間的に高精度で決定することも できる（例えば, Okuno and Miura, 2013）。

衛星重力観測 (Gravity Recovery And Climate Experiment, GRACE など）の質量収支推定で は, 現在, 南極水床全体が減少傾向とされるが (図 3 ), GIA はその推定において最大の誤差要 因となっている（福田, 2018）。一方, 衛星高度計 を用いた氷床質量収支推定では, 積雪増加による 水厚増も指摘されている (Zwally et al., 2015)。 しかし，この手法は体積を質量に換算する際の設 定条件による影響がきわめて大きく（福田, 2018）, 同じ手法でまったく異なった推定值が報告されて いるなど（Martin-Español et al., 2017），南極 水床質量収支推定に最適な手法とはいいがたい。 いずれにしても，衛星データの正確な解釈には GIA の効果を正確に見積もることが不可欠であ り, そのためには過去の南極水床変動を精度よく 復元し, 既存の GIA 融解モデルの較正, もしく はより最適な GIA 融解モデルを導くことが求め られる。

本稿では，特に東南極水床に着目して，過去の 南極水床量の定量的復元と現在の南極水床質量収 支解明の鍵となる相対的海水準変動復元と GIA モデルの高精度化, および南極水床末端における 水床融解のトリガーとなる海洋変動に関する現状 の理解についてまとめる。そして，最終間氷期以 降の東南極水床変動の高精度復元に不可欠な戦略
となる，東南極沿岸での深海・浅海-湖沼にわた る横断的な掘削研究の展望について紹介する。従 来，南極沿岸域は海水に閉ざされ観測・調查が困 難な研究の空白域であったが, 観測・掘削機器類 の進歩・開発により海底地形マッピングや堆積物 掘削が可能となった。そして, 深海・浅海-湖沼 に分布する堆積盆を漏れなくターゲットにするこ とで，時空間的に連続的な堆積物記録を取得でき る(これをシームレス掘削と呼ぶ）。「シームレス 掘削」によって得られる東南極沿岸における過去 の海水準変動を含む海洋変動記録は，東南極水床 変動メカニズムの解明への突破口となるだけでな く, GIA モデル研究に基づく地球の内部構造な ど固体地球の理解にもインパクトを与えるものと なる。

\section{II. 相対的海水準変動復元に基づく南極水床変動}

\section{1）南極大陸沿岸域における相対的海水準変動 の意味}

地球上に存在する氷床量の変動は, 海水の総量 を増減させるため, 海水準変動として全球的に観 測できる。例えば，約 2 万年前の最終氷期最盛 期（Last Glacial Maximum: LGM）以降，全球 的な海水準は，いくつかの急激な水床融解イ心゙ ントに伴う急上昇を挟みつつも，約 1.9 万年前か ら 7000 年前までの間に約 $130 \mathrm{~m}$ （全球的な水床 量変動を汎世界的な海水準変動に換算した量。水 床量相当海水準変動とも呼ばれる）上昇した（例 えば, 横山, 2002; Ishiwa et al., 2019)。しかし, 地形・地質学的な証拠から復元される過去の海水 準変動は，地域によって大きく異なる。これは， 過去に存在した巨大な北半球水床や南極水床を起 源とする融解水が海洋へ流入することによって生 じる地域的な荷重変動に対して, 地球表層およ び内部の質量再分配がおきるためである（奥野, 2018)。過去の海水準変動は, 現在の海面に対す る相対的な高さ（相対的海水準）として観測さ れ，GIAによる地殼変動のため地域ごとに異な る相対的海水準変動曲線が得られる。

世界各地で観測される相対的海水準変動と GIA モデルによって計算される相対的海水準を比較・ 
検討し, 過去の水床量・分布の変動を推定しよう とする研究が展開されている（奥野, 2018）。例 えば，約 2 万年前の LGM 以降の南極大陸沿岸に おける海水準は, 水床融解に起因する全球的な海 水準の上昇と, 観測地点周辺の水床融解（荷重解 放）による地殼隆起の影響を受け，地域ごとに大 きく異なった変動を示すことが予想される。つま り, 南極大陸沿岸の複数地点で相対的海水準変動 を復元することができれば，GIA モデルに入力 されてきた既存の GIA 融解モデルを較正し, 最 適な水床変動史を選定できる。また, 南極水床融 解の量・空間分布を定量的に推定し，さらには融 解開始時期などの変動のタイミングを決定する ことも可能となる（例えば, Okuno and Miura, 2013)。

\section{2) GIA モデルに基づく最終間氷期以降の南極 氷床融解史モデル}

GIA モデル研究は元来, 地球内部粘性構造を 推定するという観点から展開されてきた（例えば, Nakada and Lambeck, 1989)。GIA は，地球を 粘弾性的な性質をもつ球殼の変形問題として数值 モデル化することで, 地球内部の粘性構造を推定 する数少ない方法の 1 つである（奥野, 2018）。 一方, GIA モデルにおける重要な入力值には, 地球の内部構造だけでなく, 表面荷重の変化とし ての水床変動史（GIA 融解モデル）もある。つ まり, GIA モデル研究において, GIA 融解モデ ルを構築するためのグリーンランド氷床および南 極水床や北半球水床変動, そして過去からのグ ローバルな海水準変動の復元も重要な研究対象と なる。

GIA モデルにおいて, GIA 融解モデルは重要な 入力パラメータであるが，前述したとおり南極水 床変動を示す地形・地質学的データは限られてお り, 現状として推定される GIA 融解モデルは先 行研究間で大きく結果が異なっている（図 6a)。 例えば，LGM 以降に融解した南極水床の推定量 は，海水準に換算して約 $28 \mathrm{~m}$ から約 $8 \mathrm{~m}$ まで と大きな違いがあり, 融解のタイミングも Meltwater Pulse 1A（約 1.4 万年前） (Deschamps et $a l .$, 2012）に対応する GIA 融解モデルや，LGM
(約 2.0 万年前) 終了以降特別なピークをもたず 継続的な融解を示す GIA 融解モデルなどが提唱 されている。

GIA 融解モデルの制約において最も弱い点は, 現在よりも温暖な時代（約 12.5 万年前の最終間 水期）と LGM を含む時代であり，その時代の南 極水床の時空間変動の地形・地質学的データは圧 倒的に欠けている（図 $6 \mathrm{~b}$ )。現時点では，南極水 床の GIA 融解モデルの多くが，一般的に氷床か ら離れた地域の海面変化のデータから推定した 「全球的な水床量」から「北半球水床の寄与」を 差し引くことで，これらの期間の水床融解の量や 年代が推定されている。しかし，それぞれの水床 量の推定には䛊差があるため, 南極水床のどの領 域がどのようなタイミングで融解したか？を特定 することが難しく, 気候・水床モデルの制約条件 として十分なデータとなっていない。したがって, 気候・氷床モデルによる将来の海水準上昇の予測 精度を向上させるためには, 実際の水床量変動史 の証拠となる地形・地質学的デー夕を取得し，そ れらの証拠に基づき南極水床量変動とその空間分 布を直接的に復元することが有効である。

\section{3) 東南極沿岸における相対的海水準変動記録}

LGM 以降の東南極水床変動については, お もに海底地形解析や海浜・海底堆積物分析から LGM の水床の最大拡大域や後退のタイミングを 求める研究（例えば, Domack et al., 1998; Miura et al., 1998a; Berg et al., 2010; Mackintosh et al., 2011; Hillenbrand et al., 2014）や，露岩域 の基盤や迷子石の表面露出年代および ESR（電 子スピン共鳴：Electron Spin Resonance）年代 測定などからおもに氷床後退・高度低下の夕イ ミングを求める研究が進められてきた（例えば, Moriwaki et al., 1992; Takada et al., 2003; Matsuoka et al., 2006; Mackintosh et al., 2007; Yamane et al., 2011; Altmaier et al., 2010; White et al., 2011; Suganuma et al., 2014; White and Fink, 2014; Kawamata et al., 2020b)。また，露 岩域の湖沼堆積物からも水床後退によって湖沼が 成立する年代を求めることで, 過去の氷床変動が 復元されている（例えば, Hodgson et al., 2005, 
a)

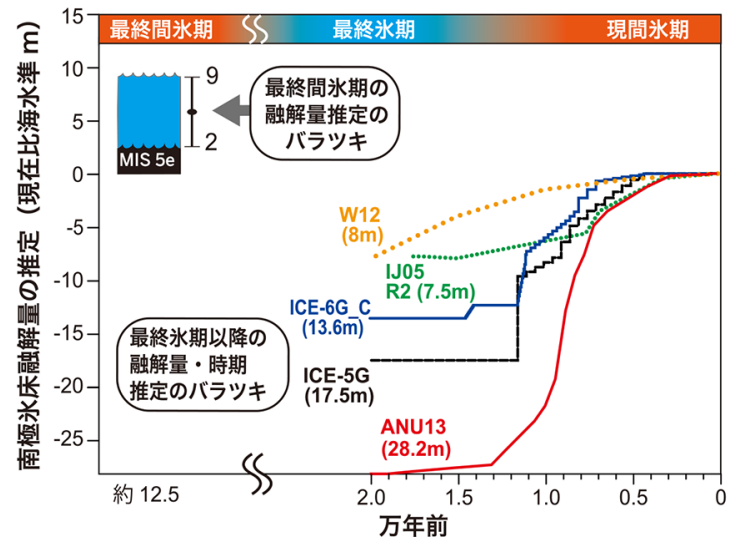

b)

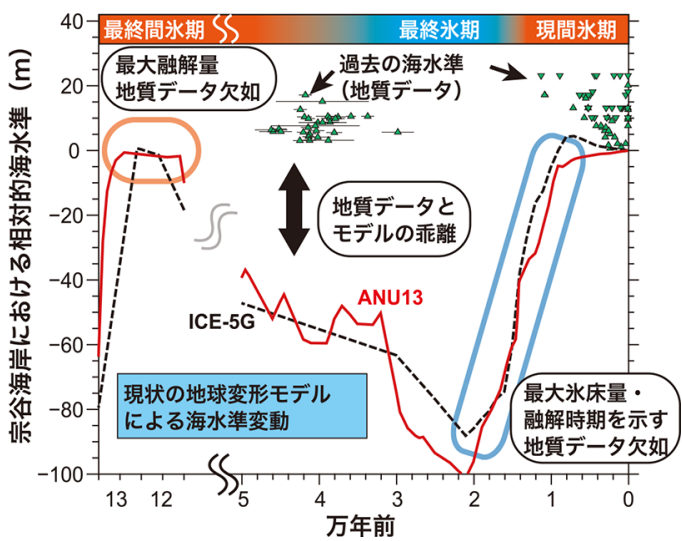

図 6 (a) 最終間水期に扔ける全球海水準と, 最終水期以降に打ける全球海水準に対する南極水床の寄与（海水準 相当)。最終水期以降の南極水床融解量の推定は異なった GIA 融解モデルに基づく（ICE-5G（Peltier, 2004）,

ICE-6G_C (Argus et al., 2014), W12 (Whitehouse et al., 2012), IJ05 (Ivins et al., 2013), おうよびANU13 （Lambeck et al., 2014). Argus et al.（2014, Figure 2）を改変．融解量の計算方法はモデル間で異なる。（b）GIA モデル（地球内部構造は以下の通り仮定： elastic lithosphere of $100 \mathrm{~km}$, upper mantle viscosity of $5 \times 10^{20} \mathrm{~Pa} \mathrm{~s}$, lower mantle viscosity of $5 \times 10^{22} \mathrm{~Pa} \mathrm{~s}$ ） から求めた東南極宗谷海岸に抢ける相対的海水準変動曲線（Ishiwa $e t$ $a l .$, 2019） と，地形・地質学的デー夕（化石・色素分析）が示す相対的海水準記録（Miura et al., 1998a; Verleyen et al., 2017). 既存の GIA モデルでは，とくに $3 \sim 5$ 万年前において地形・地質学的データが示す相対的海水準 変動を整合的に説明できないことがわかる.

Fig. 6 (a) Sea-level contribution of Antarctica to global sea level during the Last Interglacial period and since the Last Glacial Maximum to the present. Ice-loading history in this figure is as follows: ICE-5G (Peltier, 2004), ICE-6G_ C (Argus et al., 2014), W12 (Whitehouse, 2012), IJ05 (Ivins et al., 2013), and ANU13 (Lambeck et al., 2014). (b) Compilation of GIA-derived sea-level prediction (Ishiwa et al., 2019) at elastic lithosphere of $100 \mathrm{~km}$, upper mantle viscosity of $5 \times 10^{20} \mathrm{~Pa} \mathrm{~s}$, and lower mantle viscosity of $5 \times 10^{22} \mathrm{~Pa}$ s and relative sea-level observations evidenced from macrofossils (Miura et al., 1998a) and pigment analysis (Verleyen et al., 2017) in Soya coast. This comparison indicates an inconsistency between GIA based sea-level predictions and observations, especially during 30-50 ka.

2006; Phartiyal et al., 2011)。これらの研究を含 めて, LGM 以降の東南極水床融解過程の現状の 理解については, Mackintosh et al. (2014) で 詳しくレビューされている。

しかし，東南極大陸沿岸域に扔いて，過去の相 対的海水準変動の復元に取り組んだ研究は限られ ており，とくに GIA モデルの結果と比較した定 量的な水床変動解析が可能な連続的かつ詳細な デー夕は，昭和基地のある Lützow-Holm 湾東岸 (宗谷海岸) (Miura et al., 1998b; Takano et al., 2012; Verleyen et al., 2017)，その約 $500 \mathrm{~km}$ 北 東に位置する Amundsen 湾東岸の Riiser-Larsen 山（Zwartz et al., 1998a），およびさらに約 1000 $\mathrm{km}$ 東に位置する Prydz 湾東部からの報告のみで
ある（Zwartz et al., 1998b; Verleyen et al., 2005; Hodgson et al., 2009, 2016; Berg et al., 2016)

(図 7 )。また，これらの相対的海水準変動デー夕 の多くは完新世の記録であり，それ以前のデー夕 は非常に限られている。

宗谷海岸沿岸には，古くより隆起海浜堆積物が 分布することが知られ，そこに含まれる貝化石の 放射性炭素年代が完新世のものと 2 万年前以前 のものに分かれることが報告されていた（Yoshida， 1983; Hayashi and Yoshida, 1994; Igarashi et $a l .$, 1995a, b; 平川・澤柿, 1998）（図 8 ）。しかし, これらの貝化石が原地性のものか，あるいは拡大 した氷床による再堆積性のものかについては十 分に検討されていなかった（三浦ほか, 2002a）。 


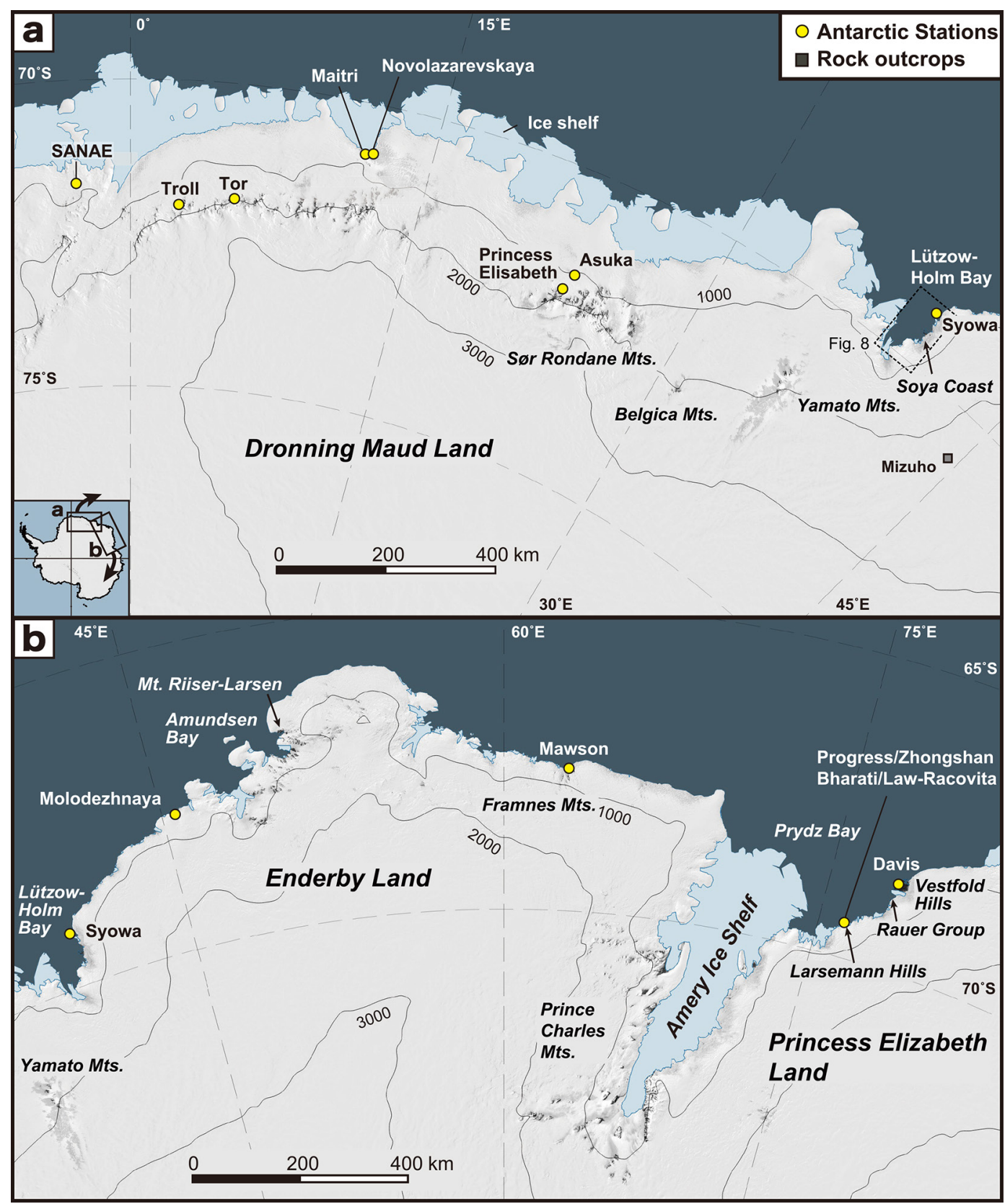

図 7 東南極における海域-陸域シームレス堆積物掘削研究が対象とする調査エリア. 東南極の Dronning Maud Land (a) と, Enderby Land および Princess Elizabeth Land（b）における露岩分布と南極観測基地の位置（黄色丸） を示した。図の作成には Quantarctica（Matsuoka et al., 2018）を使用した.

Fig. 7 Target area of seamless marine-lake sediment coring study in East Antarctica. Locations of Antarctic stations and rock outcrops are shown for Dronning Maud Land (a), and Enderby Land and Princess Elizabeth Land (b). This map is based on Quantarctica (Matsuoka et al., 2018). 


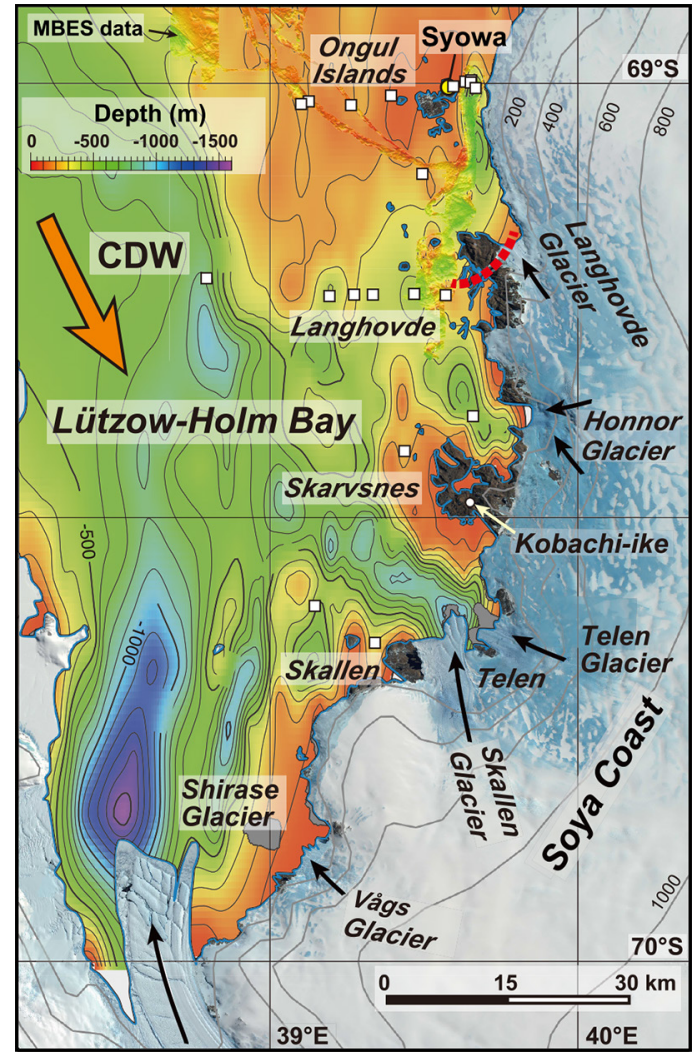

図 8 東南極宗谷海岸における衛星画像および海底地 形図. 黒矢印はおもな水河の流動方向を示す. 赤色の点線より北側は LGM において氷床に覆わ れなかったとされている (Miura et al., 1998a). 海底地形は広域の測深図の上にマルチビーム音 響測深器 (MBES: Multibeam echo sounder) の 観測で得た高分解能図を重ねて示す. Igarashi et al. (2001) で用いられた海底堆積物試料の採取 地点を白色の四角で示す。オレンジ色の矢印は 周極深層水 (Circumpolar Deep Water: CDW) の 流入を示す.

Fig. 8 Satellite image and bathymetry around the Soya Coast. Black arrows indicate flow directions of major ice streams in this area. Areas north of the red dashed line may have remained uncovered by the ice sheet during the LGM (Miura et al., 1998a). A bathymetric map is shown based on a regional bathymetric chart overlaid with a detailed one from observation results using a multibeam echo sounder (MBES). Locations of sediment samples used in Igarashi et al. (2001) are shown in white squares. Data of water depth and multibeam bathymetry were obtained during the Japanese Antarctic Research Expedition (JARE). Orange arrow indicates inflow of Circumpolar Deep Water (CDW).
その後, Maemoku et al. (1997) や Miura et al. （1998a, b, c）の一連の研究によって，宗谷海岸 に分布する隆起海浜堆積物の構造と, 含まれる原 地性貝化石の放射性炭素年代が測定され，宗谷海 岸北部において海洋酸素同位体ステージ (marine isotope stages: MIS）3（およそ3〜 万万年前） および完新世に対応する 2 つの高海水準期の存在 が確実に示された。また，MIS 3 における隆起 海浜堆積物の高度と, 完新世以降の相対的海水準 変動が復元され, 両時代の最高海面高度がそれぞ れ約 $12 \mathrm{~m}$ と約 $18 \mathrm{~m}$ であったことも示された（三 浦ほか, 2002a)。一方，宗谷海岸南部では，産出 した原地性貝化石がすべて完新世の年代を示すこ とから，LGMにおいて東南極水床は宗谷海岸南 部までしか拡大しなかった可能性が高いとされた (Miura et al., 1998b, c; Takada et al., 2003)。 この解釈は, 宗谷海岸の北部と南部で明らかに露 岩の風化度に差があること（Yoshida, 1983）と も整合的である。

また近年, 宗谷海岸沿いの湖沼堆積物の解析か らも相対的海水準変動が復元されるようになって きた。Takano et al. (2012) は，宗谷海岸南部 の Skarvsnes および Skallen（図 8 ）の湖底堆 積物における海成から湖成堆積物への変遷の夕イ ミングと, シル（湖盆集水域の最低標高地点）の 高度から相対的海水準変動を復元した。さらに Verleyen et al.（2017）は，宗谷海岸全域におい て, Takano et al. (2012) と同様に湖底堆積物の 解析と, 既存研究データをコンパイルすることで 過去 1.2 万年間の相対的海水準変動を復元した。 その結果, 宗谷海岸南部の Skarvsnes を除き, 完新世の最高海面高度は約 $17 \mathrm{~m}$ 程度であること が示された。しかし，宗谷海岸南部の Skarvsnes の小錸池（図 8 ） からは約 $32 \mathrm{~m}$ の高海水準が報 告されている (Verleyen et al., 2017)。ただし, 小鉢池における海成から湖成堆積物への変遷の年 代は 2410 cal yr BP (calendar years ago before $\mathrm{AD}$ 1950）であり，例えば Ongul 島の西オング ル大池（標高約 $13 \mathrm{~m}$ ）の淡水化が $6000 \sim 5000$ cal yr BP と推定されていること (Verleyen et $a l ., 2017 ）$ と比較すると，有意に若い。Verleyen 
et al.（2017）は，その原因として，氷床荷重に 応答した断層システムの再活動の可能性を指摘し ている。しかし，小鉢池には降雪以外の淡水供給 源がほとんどないことから，この堆積環境の変化 が相対的海水準変動を示していると解釈できるか については今後の検証が必要である。また，これ らの先行研究では, 湖底堆積物から氷床後退の夕 イミングが推定されているが，従来の押込式コア ラー（香月ほか, 2019）では基盤（岩）直上まで 達する堆積物採取が困難であること（菅沼ほか, 2019)，採取された堆積物の最下部において氷床 後退を示す岩相（水河性シルト層）が報告されて いないことから, 従来得られている湖沼堆積物最 下部の年代值は氷床後退年代 (水床から解放され て湖沼が成立した年代）を示していない可能性が ある（川又ほか, 2020a; Kawamata et al., 2020b）。

Riiser-Larsen 山に执いては（図 7b)，アデリー ペンギンのルッカリー遺物を用いて完新世におけ る相対的海水準変動が推定されている（三浦ほ か, 2002b)。アデリーペンギンは，夏期間に沿岸 の露岩で集団営巣し，ルッカリー（集団で子育て をする場所）を形成する。ルッカリーには，グア ノと呼ばれる糞などに含まれる有機物の遺物が累 積していくため，放射性炭素年代測定によって営 巣していた年代を決定することが可能である。三 浦ほか (2002b) は, Riiser-Larsen 山のルッカ

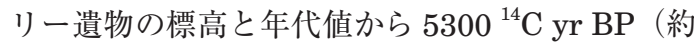
$4100 \mathrm{cal} \mathrm{yr} \mathrm{BP)}$ に当時の海水準が $15 \mathrm{~m}$ 以下, $2700{ }^{14} \mathrm{C}$ yr BP（約 $1600 \mathrm{cal} \mathrm{yr} \mathrm{BP）には} 6 \mathrm{~m}$ 以 下であったことを示した。また，周辺に残る隆起 海浜とみられる地形の上限高度が $16 \sim 18 \mathrm{~m}$ で あることや，宗谷海岸で復元された完新世の最高 海水準とほほ同等の上限高度であることも明らか にした（Zwartz et al., 1998a）。

一方, Prydz 湾東岸では, Vestfold Hills (Zwartz et al., 1998b), Larsemann Hills (Hodgson et al., 2009; Verleyen et al., 2004, 2005)，および Rauer Group（Berg et al., 2010） において, 相対的海水準変動や水床変動の復元が 試みられてきた（図 7b)。Hodgson et al.(2016) は，この地域での海水準デー夕をまとめ，完新
世以降の最高海面期が 9411 $7564 \mathrm{cal} \mathrm{yr} \mathrm{BP}$ で あり，最高海水準が約 $8 \mathrm{~m}$ であったと報告して いる (Hodgson et al., 2016)。一方，MIS 3 につ いては, Hodgson et al. (2009) が Larsemann Hills の海水準の下限高度を $8 \mathrm{~m}$ と推定している。 この結果は, Berg et al. (2016) による Rauer Group での海水準推定值（ $\pm 15 \mathrm{~m} ）$ 内に収まる。 さらにBerg et al. (2016) は，周辺露岩の表面 露出年代に基づき, MIS 3 においてこの一帯は氷 床に覆われていなかったとしている。これらの研 究によって, MIS 3 には全球的に海水準が現在 よりも低下していたにもかかわらず，東南極水床 の拡大域は少なくとも現在と同じ程度であったこ とが明らかになった。

以上のように，地点は限られるものの，東南極 水床沿岸の複数地点において，完新世初期〜中期 の海水準が現在よりもかなり高かったことが指摘 されている。このことは, その後の水床融解に 伴う GIAによって海岸が隆起したことを示唆す る。実際，極地から遠く離れ，テクトニクス的に も安定な地域の相対的海水準変動の解析結果は, 完新世中期以降に $2 \sim 3 \mathrm{~m}$ 程度の海面上昇に相 当する氷床融解（完新世融解）を示唆しており (Nakada and Lambeck, 1988)，この融解は南極 水床起源であると結論づけられている（Nakada et al., 2000; Stocchi et al., 2009)。しかし，南極 氷床のどの領域がこの海水準上昇におもな寄与を 果たしたのかについてはよくわかっていない。

なお，南極域における放射性炭素年代の海洋り ザーバ効果については, Yoshida and Moriwaki （1979）が昭和基地付近で採取された現生生物 の ${ }^{14} \mathrm{C}$ 年代の平均を $1120{ }^{14} \mathrm{C} \mathrm{yr} \mathrm{BP}$ と報告して いることから, Verleyen et al. (2017) もこの結 果に基づいて暦年較正を行っている。ただし,

Yoshida and Moriwaki（1979）は核実験の大気 への効果が大きい時代（1975 年）に採取された 試料を年代測定しているほか, 海洋環境の変化が 激しい同海域において過去にも海洋リザーバ効果 が同程度であったかも不明であり，数百年といっ た短いタイムスケールの議論をする場合には注意 が必要である。 
一方，前述のように東南極の Lützow-Holm 湾 と Prydz 湾では, MIS 3 の海水準データが得ら れており, MIS 3 の海水面が現在と同程度かそ れ以上であったと報告されている（三浦ほか, 2002a; Hodgson et al., 2009; Berg et al., 2016)。 しかし, 提案されている GIA 融解モデルによる 氷床変動史は MIS 3 の時期において $-40 \mathrm{~m}$ 以下 の海水準を示しており，両者は一致しない（図 $6 \mathrm{~b})$ 。したがって, 水床変動史の再検討が必要と されている。

\section{III. 南極における海域-陸域シームレス堆積物 掘削研究の戦略と展望}

本章では，現在計画中の南極における『海域一 陸域シームレス堆積物掘削』研究について, 南極 周辺の海水準や氷床変動デー夕取得に向けた具体 的戦略や, 従来の南極水床変動史復元研究が解決 できなかった問題点に対して本研究計画がもつ優 位性について詳述する。

\section{1）露岩〜沿岸域の凹状地形に残される海水準 変動記録}

南極沿岸における相対的海水準変動の復元に最 も有効な方法は, 湖沼や浅海域に分布する堆積物 を採取・解析することである。これらの堆積物か らは，含まれる微化石やその化学生成物（色素）, 堆積相，および間隙水の塩分などに基づき，堆積 当時の環境（海底か湖底か）を推定することがで きる。例えば，微化石として堆積物中に保存され る植物プランクトンの一種, 珪藻は生息域の塩分 変化に鋭敏に反応し群集組成を変化させるため, 珪藻化石の種構成（海生種，汽水種，淡水種） から堆積当時の水環境を推測できる（岩佐ほか, 2000; Verleyen et al., 2017)。また，光合成生物 がもつ色素（クロロフィル類およびカロテノイド 類）のなかには分類群ごとに特有のものがあるた め, 堆積物中の色素組成を求めることでも, 光合 成生物群集の分類群組成を再構築し, 当時の水環 境（海水-汽水一淡水など）の復元が可能となる。

南極沿岸は, 前述のように全球的な海水準変動 と氷床融解に伴う荷重解放による地款隆起の影響 を受け，同一地点においても時代とともに相対的
海水準が大きく複雑に変化する（例えば, Zwartz et $a l ., 1998 \mathrm{~b})$ 。例えば，現在の南極沿岸湖沼の 一部は，LGM の低海面期には陸上にあったが， LGM 以降の相対的海水準のピーク時には海面下 に没していた可能性がある。また，南極沿岸湖沼 の多くは LGM 以後の水床後退時に成立したと考 えられることから, 湖沼堆積物の堆積開始は氷 床後退のタイミングに関する示唆も与える。つ まり，沿岸湖沼堆積物は，調査域における南極 水床変動史および氷床融解プロセスを理解する 上で重要なデー夕を有している（例えば, Zwartz et al., 1998b; 三浦, 2002; Hodgson et al., 2009; Watcham et al., 2011; Berg et al., 2016)。一方, 南極沿岸の浅海域は，LGM の低海面期に陸上に 露出した部分もあり，現在海面下に存在する凹状 地形には, かつて淡水湖が存在した可能性があ る。この海底の凹状地形（かつての淡水湖）は, その後の海水準上昇で海面下に没したために，凹 状地形の堆積物に湖から海へと至る変化（海水 準の変動）が認められれば，LGM 以後の相対的 海水準変動を知ることができる（Hodgson et al., 2016)。つまり, 南極沿岸の水深・標高の異なる 凹状地形や湖沼の堆積物から堆積環境や堆積年代 を明らかにすることによって，これまで南極域で は得られていなかった最終間水期以降の連続的な 相対的海水準変動の復元が可能となる（図 9a)。 とくに, LGM から完新世にかけての南極氷床融 解史は, 対象となる堆積物が海面下に存在し, 採 取が困難であるため，ほとんどデー夕が得られて いないこともありきわめて重要である。また，最 終間水期についても，相対的海水準の証拠が沿岸 の湖沼域などに残されている可能性があるが,

これまでに Larsemann Hills の記録（Hodgson et $a l .$, 2006） 以外に堆積したタイミングを明確 に言及されているものはなく，東南極のとくに Dronning Maud Land, Enderby Land, および Princess Elizabeth Land などの地域の浅海-湖 沼域において（図 7 ), 新規にデー夕を取得する 意義は大きい。

\section{2) 堆積物から紐解く氷床融解メカニズム}

南極沿岸深海域における海底堆積物の古海洋プ 


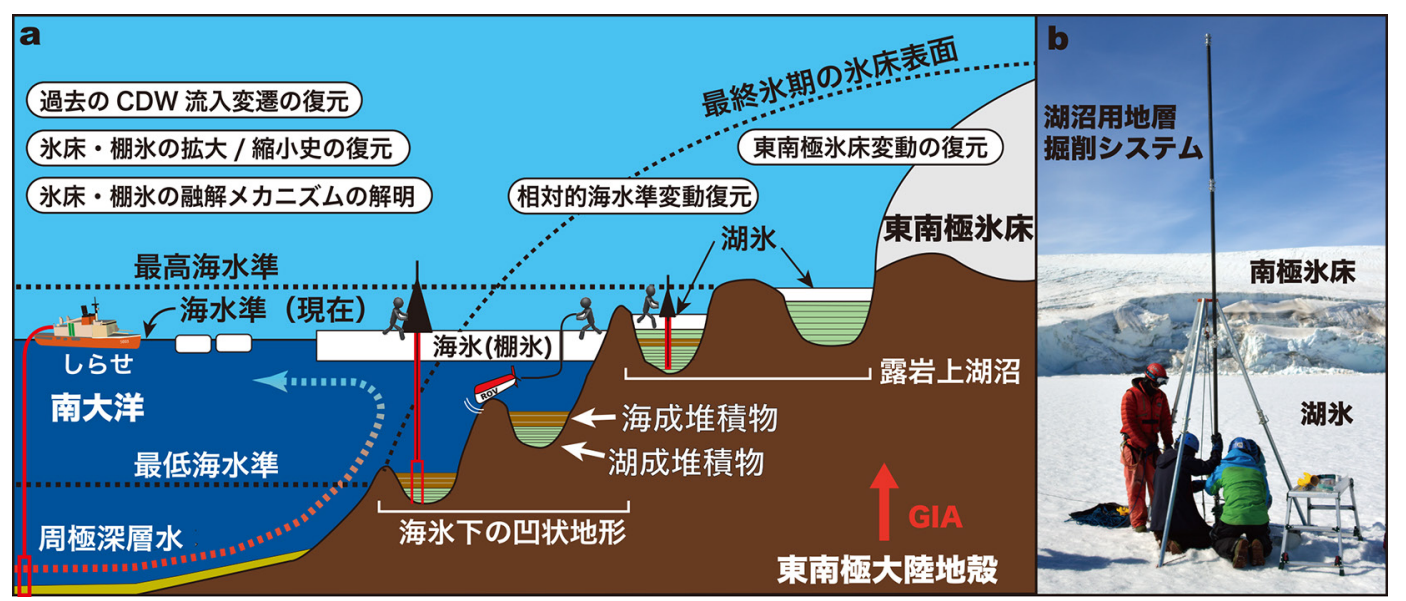

図 9 (a) 海域-陸域シームレス堆積物掘削が取り組む重要研究課題と水下地形探査の模式図. (b) 可搬型パーカッ ションピストンコアラー（菅沼ほか, 2019）を用いた南極での湖沼掘削風景.

Fig. 9 (a) Schematic figure showing an image of seamless sediment coring and bathymetry survey on the ice with scientific topics to be addressed. (b) Photograph showing lake sediment coring using a percussion piston corer (Suganuma et al., 2019) in Antarctica.

ロキシ分析は，過去の水床変動の高精度復元はも とより, 水床融解メカニズムに迫ることも可能と する。近年, 西南極水床において, CDW の流入 が棚水の底面融解を加速させる現象が詳しく解析 されるようになってきた（例えば, Nakayama et $a l ., 2018)$ 。南極沿岸には，CDW だけでなく, 棚水底面融解水や南極沿岸水など，物理・生物地 球化学的特徵 (水温·塩分 $\cdot \mathrm{H} / \mathrm{O} / \mathrm{C}$ 同位体比) と生物相がそれぞれ異なる水が存在するため, 古 海洋プロキシ分析から，氷床融解とトリガーに なった海洋変動（CDW の流入）を明らかにでき る。例えば，西南極水床の Pine Island Bay で は, 海底堆積物に含まれる浮遊性・底生有孔虫殼 の酸素・炭素同位体比分析から, 過去の CDW の 流入実態と西南極水床融解の関係が議論されて いる (Hillenbrand et al., 2017)。彼らは, Pine Island Bayにおいて約 7500 年前までは CDW が 活発に流入し棚水を後退させたが，その後は流入 が停止し，1940 年代以降に CDW の流入が再び 活発になったことを示した。一方, Lützow-Holm 湾においても, Igarashi et al. (2001) による先 駆的な研究によって, 浮遊性有孔虫化石の保存状 態や底生有孔虫の群集組成から過去の CDW の流
入の可能性が指摘されているが，東南極氷床変動 との関係については十分に議論されていない。今 後, 浮遊性・底生有孔虫殼の酸素・炭素同位体比 分析を用いて CDW の流入を解析し，さらに有孔 虫殼の $\mathrm{Mg} / \mathrm{Ca}$ 比（水温の指標）分析と酸素同位 体比分析によって, CDW と棚水底面融解水の水 温・塩分を復元し, 両者の差を推定することで, 過去の水床融解の定量化も可能となるかもしれな い。

さらに近年，海底堆積物中の ${ }^{10} \mathrm{Be}$ 濃度が，南 極沿岸において堆積物の供給源や堆積環境を示 すプロキシとして利用できることがわかってき た（例えば, Sjunneskog et al., 2007; Yokoyama et al., 2016; White et al., 2019)。 ${ }^{10} \mathrm{Be}$ は，超新 星爆発起源の高エネルギーの銀河宇宙線と酸素 · 窒素原子の核破砕反応によっておもに大気上層で 生成され，降雨・降雪によって速やかに大気中か ら陸・海域に運搬される。ただし, 南極大陸の場 合は，雪は時間とともに氷床に変化するが，基本 的に融解ではなく南極水床の流動によって沿岸ま で運ばれ，そこで融解または氷山として流出す る。White et al. (2019) は, Prydz 湾において, $\mathrm{CDW}$ の流入が少ない棚氷下の堆積物には外洋域 
と比べて数分の 1 以下の ${ }^{10} \mathrm{Be}$ しか存在しないこ とを報告している。したがって，南極沿岸の海底 堆積物中の ${ }^{10} \mathrm{Be}$ 濃度によって, その地点が氷床 や棚氷から解放された時期, すなわち南極水床変 動を明らかにできる。一方，Lützow-Holm 湾の 沿岸陸域における詳細な地形調査が既に行われて いるが (Miura et al., 1998a, b)，LGM における 東南極水床・棚氷の最大拡大域やその後の後退過 程は明らかになっておらず，空間的な東南極水床 後退過程に関する議論はされてこなかった。もし LGM 以降における東南極水床・棚水変動の高精 度復元ができれば，宗谷海岸沿岸で報告されてい る東南極水床後退の詳細なデー夕とあわせて, 東 南極 Lützow-Holm 湾における三次元的な東南極 氷床変動と, その変動メカニズムの解明も可能と なる。将来的には, これらの成果から氷床モデル を用いた定量的な水床変動復元に不可欠な制約条 件デー夕を提供できるかもしれない。

\section{3) 堆積物掘削手法}

これまで述べてきたように，南極大陸沿岸の相 対的海水準変動を復元するためには，南極の多様 な条件に対応できる堆積物掘削手法が必要とな る。例えば，通常は海水に閉ざされている南極沿 岸の浅海や，露岩域に存在する湖沼において，相 対的海水準変動を記録する堆積物を連続的に採取 しなければならない。しかし，東南極沿岸は夏期 にも海水が広がる上に，浅海域には大型船舶が侵 入できない（図 4 ）。一方，大陸上もアクセスが きわめて困難であり，重機を用いた運搬が必要と なるような大がかりな堆積物掘削は難しい。そこ で従来は，押込式コアラーなどの軽量・簡便な掘 削機器を用いて堆積物の採取が行われてきた。し かし，前述のように堆積物が十分に柔らかい場合 を除いて，軽量・簡便なコアラーでは $3 \sim 4 \mathrm{~m}$ 程度の堆積物の採取が限界であり，これを超える 長尺の堆積物や粗粒堆積物の採取，および湖沼の 成立を知る上で不可欠となる基盤直上の堆積物の 採取は困難であった（菅沼ほか, 2018）。

このように南極における湖沼や沿岸域の堆積物 掘削には非常に困難な条件が揃うが，冬期間に 限っていえば湖面や海面が完全に凍結するため,
そこをプラットフォームとして湖水・海水上から 堆積物を採取することが可能である。菅沼ほか （2019）は，この特性を利用すべく新たに可搬型 パーカッションピストンコアラーを開発した（図 9b)。このコアラーは，山上湿地掘削用に開発さ れた可搬型パーカッションコアリングシステム（金 田ほか, 2018）に着想を得て，エンジン式ハンド ブレーカーを掘削動力としつつ，ピストンシステ ムを用いたポリカーボネート製コアラーなど軽量 なシステムを用いており，湖沼だけでなく，水深 $30 \mathrm{~m}$ 程度以下ならば浅海域においても, 従来の 押込式コアラーでは難しかった長尺かつ基盤まで 到達する堆積物の採取が可能である。

これまで，南極大陸沿岸のとくに浅海域におけ る海底地形情報がきわめて限られていたため, 海 面下における凹状地形の存在や分布はあまりわ かっていなかった。一方，近年の技術革新・ロジ スティクスの進歩によって，浅海域については氷 上から操作型海中ロボット（Remotely Operated Vehicle；ROV）を水下に投入し，運用すること で，これまで困難であった南極沿岸における海底 地形マッピングが実現可能となりつつある。また, 海水が緩む夏期には，調査エリアは限られるもの のゾディアックボートなどのゴムボートに魚群探 知機などを応用した音響測深機を搭載することに よって (Yamasaki et al., 2017), 海底地形のマッ ピングを行うことも可能になるかもしれない。

また, 砕水船「しらせ」に大口径重力式コア ラー（口径 $12 \mathrm{~cm}$ ，コア長 $5 \mathrm{~m}$ ）を新たに導入す ることで，氷上からの掘削が不可能な南極沿岸の 深海域においても海底堆積物の採取実現が可能と なる。これによって，海水に閉ざされている南極 沿岸においても，海水の緩む夏期に砕水船を用い ることで通常の海洋と同様に海底堆積物の掘削が 実現できる（図 9a）。また，近年は砕水船の活動 域において, 搭載されたマルチビーム音響測深器 の活用によって詳細な地形デー夕の取得が進めら れている（図 8 )。さらには，海水・棚水下の領 域においても，マルチビーム音響測深器を無人潜 水機に搭載することで，将来的にはより高分解能 の海底地形データ（1 m オーダー以下）の取得も 
可能である（藤井・野木, 2018）。CDW の流入は 地形的な制約を強く受けていることから（Nakayama et al., 2018)，海洋変動記録と詳細な海底 地形デー夕を組み合わせることで，海洋モデルを 過去の棚水・氷床融解プロセスの解明に応用でき れば，研究のブレークスルーに繋がると期待され る。

以上のように，近年の技術革新や新たな機器開 発, そして既存機器の改造・応用などによって, 最終間水期以降の東南極水床変動の復元に不可欠 な南極沿岸の深海・浅海-湖沼における堆積物掘 削が可能となりつつある。本稿で紹介した「東南 極における海域-陸域シームレス堆積物掘削計画」 は，東南極の Dronning Maud Land や Prydz 湾 をターゲットにして，各国の基地や砕水船「しら せ」を拠点として，国内外のさまざまな専門分 野の研究者と協力し, 相対的海水準変動および水 床融解と海洋変動の復元を進めていく。このプロ ジェクトが取り組む東南極沿岸における地球気候 システムの重要な要素と, 研究トピックを図 $9 \mathrm{a}$ に模式的に示した。本プロジェクトにより取得さ れる地形・地質学的なデータと, 将来的なモデル 研究との融合は，南大洋および南極水床が種々の 相互作用を通じて地球の環境変動に及ぼす影響 や，そのメカニズムの解明に繋がるものとなるだ ろう。

\section{IV. ま と め}

南極水床の融解過程には, 一度超えてしまうと 容易に後戻りできない「Tipping point」が存在 すると考えられている。しかし，南極氷床におい て，気候モデルによる再現と観測事実の差は依 然として大きく（IPCC, 2013），南極水床融解の Tipping point の実態は不明である。南極水床末 端の融解メカニズムの理解は, Tipping point の 実態把握に不可欠なため，LGM 以降の急激な水 床融解時の融解量や高海水準時の海水準の制約が 注目を集めており，海水下での堆積物掘削が各国 で計画されている。しかし，海底地形マッピング も含めて，南極沿岸での地層掘削が困難であるこ となどからいまだ実現されていない。したがっ
て，本研究で実施する「東南極における海域-陸 域シームレス堆積物」は，同分野の研究における ブレークスルーとなる可能性がある。本研究計画 によって採取される南極沿岸の堆積物は，これま で得られていなかった時代（最終間水期から現代 まで）の相対的海水準変動に関する直接的なデー 夕を含んでいるだろう。それに加えて，南極水床 末端における水床融解とトリガーになった海洋変 動をそれらのデータから復元することは，南極水 床変動研究の突破口となる。

\section{謝 辞}

東南極に扔ける海域一陸域シームレス堆積物掘削研 究は, 現在進行中の新学術領域研究「熱-水一物質の巨 大リザーバ 全球環境変動を駆動する南大洋・南極水 床（代表川村賢二）」のなかでさまざまな分野の方々

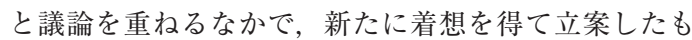
のである。とくに，国立極地研究所の三浦英樹博士に は，南極に扔ける地形・地質学的な研究史について丁 寧にご教示いただくとともに，本稿にも建設的なコメ ントをいただいた。また，これまでリュッォ・ホルム 湾や南大洋の環境変動研究の知見については法政大学 の前圭英明博士抒よび澤柿教伸博士，復建調查設計株 式会社の五十嵐厚夫博士，高知大学の池原 実博士に,

気候・氷床モデルシミュレーションについては東京大 学大気海洋研究所の阿部彩子博士㧍よび海洋研究開発 機構の齋藤冬樹博士に, 操作型海中ロボットについて は東京大学生産技術研究所の巻俊宏博士および山縣広 和博士と国立極地研究所の野木義史博士に, 周極深層 水の流入や棚水底面融解については国立極地研究所の 田村岳史博士および海洋研究開発機構の草原和弥博士 に，ゴムボートを用いた音響測深について京都大学 防災研究所の山崎新太郎博士に, そして深海・浅海一 湖沼に扮ける生物地球化学的研究全般については須 藤 斎博士および田邊優貴子博士に，ご指導いただい た。本研究は, 東レ科学技術研究助成(代表者菅沼悠 介)，文部科学省科学研究費補助金基盤研究（B）課題 番号 16H05739（代表者菅沼悠介），基盤研究（A）課 題番号 19H00728（代表者菅沼悠介）, 新学術領域研 究 17H06321（代表者福田洋一），および研究プロジェ クトKP306（代表者野木義史）の一部を使用した。ま た，一部の図の作成には，ノルウェー極地研のソフト ウェア（Quantarctica）を使用した。 


\section{文献}

Altmaier, M., Herpers, U., Delisle, G., Merchel, S. and Ott, U. (2010): Glaciation history of Queen Maud Land (Antarctica) reconstructed from in-situ produced cosmogenic ${ }^{10} \mathrm{Be},{ }^{26} \mathrm{Al}$ and ${ }^{21} \mathrm{Ne}$. Polar Science, 4, 42-61.

Argus, D.F., Peltier, W.R., Drummond, R. and Moore, A.W. (2014): The Antarctica component of postglacial rebound model ICE-6G_C (VM5a) based on GPS positioning, exposure age dating of ice thicknesses, and relative sea level histories. Geophysical Journal International, 198, 537-563.

Berg, S., Wagner, B., Cremer, H., Leng, M.J. and Melles, M. (2010): Late Quaternary environmental and climate history of Rauer Group, East Antarctica. Palaeogeography, Palaeoclimatology, Palaeoecology, 297, 201-213.

Berg, S., White, D.A., Bennike, O., Fülöp, R.-H., Fink, D., Wagner, B. and Melles, M. (2016): Unglaciated areas in East Antarctica during the Last Glacial (Marine Isotope Stage 3)-New evidence from Rauer Group. Quaternary Science Reviews, 153, 110.

DeConto, R.M. and Pollard, D. (2016): Contribution of Antarctica to past and future sea-level rise. $\mathrm{Na}$ ture, 531, 591-597.

Deschamps, P., Durand, N., Bard, E., Hamelin, B., Camoin, G., Thomas, A.L., Henderson, G.M., Okuno, J. and Yokoyama, Y. (2012): Ice-sheet collapse and sea-level rise at the Bølling warming 14,600 years ago. Nature, 483, 559-564.

Domack, E., O’Brien, P., Harris, P., Taylor, F., Quilty, P.G., De Santis, L. and Raker, B. (1998): Late Quaternary sediment facies in Prydz Bay, East Antarctica and their relationship to glacial advance onto the continental shelf. Antarctic Science, 10, 234-244.

Dutton, A., Carlson, A.E., Long, A.J., Milne, G.A., Clark, P.U., DeConto, R., Horton, B.P., Rahmstorf, S. and Raymo, M.E. (2015): Sea-level rise due to polar ice-sheet mass loss during past warm periods. Science, 349, aaa4019.

Edwards, T.L., Brandon, M.A., Durand, G., Edwards, N.R., Golledge, N.R., Holden, P.B., Nias, I.J., Payne, A.J., Ritz, C. and Wernecke, A. (2019): Revisiting Antarctic ice loss due to marine ice-cliff instability. Nature, 566, 58-64.

Favier, L., Durand, G., Cornford, S.L., Gudmundsson, G.H., Gagliardini, O., Gillet-Chaulet, F., Zwinger, T., Payne, A.J. and Le Brocq, A.M. (2014): Retreat of Pine Island Glacier controlled by marine ice-sheet instability. Nature Climate Change, 4, 117-121.

Fretwell, P. and 59 others (2013): Bedmap2: Improved ice bed, surface and thickness datasets for Antarctica. Cryosphere, 7, 375-393.

藤井昌和・野木義史 (2018)：音波探査で海底を見る：
海底地形に記録された地球環境変動. 低温科学, 76 , 269-284. [Fujii, M. and Nogi, Y. (2018): Acoustic mapping of the seafloor features: Implication for global environmental change. Low Temperature Science (Teion Kagaku), 76, 269-284. (in Japanese with English abstract)]

福田洋一 (2018): 衛星観測による南極水床質量収支. 低温科学，76，187-204. [Fukuda, Y. (2018): Satellite observations of the Antarctic ice-sheet mass balance. Low Temperature Science (Teion Kagaku), 76, 187-204. (in Japanese with English abstract) ]

Hayashi, M. and Yoshida, Y. (1994): Holocene raised beaches in the Lützow-Holm Bay region, East Antarctica (special issue). Memoir National Institute of Polar Research, 50, 49-84.

Hillenbrand, C.-D., Bentley, M.J., Stolldorf, T.D., Hein, A.S., Kuhn, G., Graham, A.G.C., Fogwill, C.J., Kristoffersen, Y., Smith, J.A., Anderson, J.A., Larter, R.D., Melles, M., Hodgson, D.A., Mulvaney, R. and Sugden, D.E. (2014): Reconstruction of changes in the Weddell Sea sector of the Antarctic Ice Sheet since the Last Glacial Maximum. Quaternary Science Reviews, 100, 111-136.

Hillenbrand, C.-D., Smith, J.A., Hodell, D.A., Greaves, M., Poole, C.R., Kender, S., Williams, M., Andersen, T.J., Jernas, P.E., Elderfield, H., Klages, J.P., Roberts, S.J., Gohl, K., Larter, R.L. and Kuhn, G. (2017): West Antarctic Ice Sheet retreat driven by Holocene warm water incursions. Nature, 547, 4348.

平川一臣・澤柿教伸 (1998): 宗谷海岸の隆起海成堆積 物から得られた貝化石の ${ }^{14} \mathrm{C}$ 年代一JARE-35（19931994）の資料一. 南極資料，42，151-167. [Hirakawa, K. and Sawagaki, T. (1998): Radiocarbon dates of fossil shells from raised beach sediments along the Soya Coast, East Antarctica-A report on a geomorphological survey during JARE-35 (19931994) - Antarctic Record (Nankyoku Shiryo), 42, 151-167 (in Japanese with English abstract) ]

Hodgson, D.A., Verleyen, E., Sabbe, K., Squier, A.H., Keely, B.J., Leng, M.J., Saunders, K.M. and Vyverman, W. (2005): Late Quaternary climate-driven environmental change in the Larsemann Hills, East Antarctica, multi-proxy evidence from a lake sediment core. Quaternary Research, 64, 83-99.

Hodgson, D.A., Verleyen, E., Squier, A.H., Sabbe, K., Keely, B.J., Saunders, K.M. and Vyverman, W. (2006): Interglacial environments of coastal east Antarctica: Comparison of MIS 1 (Holocene) and MIS 5e (Last Interglacial) lake-sediment records. Quaternary Science Reviews, 25, 179-197.

Hodgson, D.A., Verleyen, E., Vyverman, W., Sabbe, K., Leng, M.J., Pickering, M.D. and Keely, B.J. (2009): A geological constraint on relative sea level in marine isotope stage 3 in the Larsemann Hills, Lambert glacier region, East Antarctica (3136633228 cal yr BP). Quaternary Science Reviews, 28, 
2689-2696.

Hodgson, D.A., Whitehouse, P.L., De Cort, G., Berg, S., Verleyen, E., Tavernier, I., Roberts, S.J., Vyverman, W., Sabbe, K. and O'Brien, P. (2016): Rapid early Holocene sea-level rise in Prydz Bay, East Antarctica. Global and Planetary Change, 139, 128140.

Igarashi, A., Harada, N. and Moriwaki, K. (1995a): Marine fossils of 30-40 ka in raised beach deposits, and late Pleistocene glacial history around LützowHolm Bay, East Antarctica. Proceedings of the NIPR Symposium on Antarctic Geosciences, 8, 219-229.

Igarashi, A., Numanami, H., Tsuchiya, Y., Harada, N., Fukuchi, M. and Saitoh, T. (1995b): Radiocarbon ages of molluscan shell fossils in raised beach deposits along the east coast of Lützow-Holm Bay, Antarctica, determined by accelerator mass-spectrometry. Proceedings of NIPR Symposium Polar Biology, 8, 154-162.

Igarashi, A., Numanami, H., Tsuchiya, Y. and Fukuchi, M. (2001): Bathymetric distribution of fossil foraminifera within marine sediment cores from the eastern part of Lützow-Holm Bay, East Antarctica, and its paleoceanographic implications. Marine Micropaleontology, 42, 125-162.

IPCC (2013): Climate Change 2013: The Physical Science Basis. Contribution of Working Group I to the Fifth Assessment Report of the Intergovernmental Panel on Climate Change edited by Stocker, T.F., Qin, D., Plattner, G.-K., Tignor, M., Allen, S.K., Boschung, J., Nauels, A., Xia, Y., Bex, V. and Midgley, P.M., Cambridge University Press.

Ishiwa. T., Yokoyama, Y., Okuno, J., Obrochta, S., Uehara, K., Ikehara, M. and Miyairi, Y. (2019): A sea-level plateau preceding the Marine Isotope Stage 2 minima revealed by Australian sediments. Scientific Reports, 9, 6449.

Ivins, E.R. and James, T.S. (2005): Antarctic glacial isostatic adjustment: A new assessment. Antarctic Science, 17, 541-553.

Ivins, E.R., James, T.S., Wahr, J., Schrama, E.J.O., Landerer, F.W. and Simon, K.M. (2013): Antarctic contribution to sea level rise observed by GRACE with improved GIA correction. Journal of Geophysical Research, 118, 3126-3141.

岩佐朋美 - 坂東忠司 - 中村俊夫 - 伊村 智 (2000)：湖 底藻類堆積物の $\mathrm{AMS}{ }^{14} \mathrm{C}$ 年代からみた昭和基地周辺 の環境変遷. 名古屋大学加速器質量分析計業績報告 書, 11, 74-80. [Iwasa, T., Bando, T., Nakamura, T. and Imura, S. (2000): The environmental changes presumed by $\mathrm{AMS}^{14} \mathrm{C}$ ages of algal sediments in antarctic lakes, near the Showa Station. Summaries of Researches Using AMS at Nagoya University, 11, 74-80 (in Japanese with English abstract)]

金田平太郎・柏原真太郎・小村慶太朗 (2018)：山上 湿地掘削のための可搬型パーカッションコアリング システム. 月刊地球号外, 69, 112-120. [Kaneda,
H., Kashihara, S. and Komura, K. (2018): Portable engine-driven percussion coring system for study of dammed-up depressions on mountain ridges. Chikyu Monthly (Gekkan Chikyu Gogai), 69, 112120.

香月興太・瀬戸浩二 - 菅沼悠介 - Dong Yoon Yang (2019): 湖底堆積物調査における携帯型採泥器具の 種類と特徵について. 地学雑誌, 128, 359-376.

[Katsuki, K., Seto, K., Suganuma, Y. and Yang, D.Y. (1990): Holocene coastal seismotectonics in the eastern margin of the Sea of Japan. Journal of Geography (Chigaku Zasshi), 128, 359-376. (in Japanese with English abstract) ]

勝又勝郎 (2018): 南極底層水と全球海洋子午面循環. 低温科学, 76, 1-12. [Katsumata, K. (2018): Antarctic bottom water and global ocean meridional overturning circulation. Low Temperature Science (Teion Kagaku), 76, 1-12. (in Japanese with English abstract) ]

Kawamura, K. and 63 others (2017): State dependence of climatic instability over the past 720,000 years from Antarctic ice cores and climate modeling. Science Advances, 3, e1600446.

川又基人 · 菅沼悠介 · 土井浩一郎 - 澤柿教伸 · 服部晃久 (2020a): 水河地形調査と表面露出年代に基づく東南 極宗谷海岸南部 Skarvsnes における水床後退過程の 復元. 地学雑誌, 129，315-336. [Kawamata, M., Suganuma, Y., Doi, K., Sawagaki, T. and Hattori, A. (2020a): Reconstruction of ice sheet retreat history at Skarvsnes, southern part of the Soya Coast, East Antarctica based on glacial landforms and surface exposure ages. Journal of Geography (Chigaku Zasshi), 129, 315-336. (in Japanese with English abstract) ]

Kawamata, M., Suganuma, Y., Doi, K., Misawa, K., Hirabayashi, M., Hattori, A. and Sawagaki, T. (2020b): Abrupt Holocene ice-sheet thinning along the southern Soya Coast, Lützow-Holm Bay, East Antarctica, revealed by glacial geomorphology and surface exposure dating. Quaternary Science Reviews, 247, 106540.

Kürschner, W.M., van der Burgh, J., Visscher, H. and Dilcher, D.L. (1996): Oak leaves as biosensors of late Neogene and early Pleistocene paleoatmospheric $\mathrm{CO}_{2}$ concentrations. Marine Micropaleontology, 27, 299-312.

Lambeck, K., Rouby, H. Purcell, A. Sun, Y. and Sambridge, M. (2014): Sea level and global ice volumes from the Last Glacial Maximum to the Holocene. Proceedings of the National Academy of Sciences, 11, 15296-15303.

Lisiecki, L.E. and Raymo, M.E. (2005): A PliocenePleistocene stack of 57 globally distributed benthic $\delta \mathrm{O}^{18}$ records. Paleoceanography, 20, PA1003.

Mackintosh, A., White, D., Fink, D., Gore, D.B., Pickard, J. and Fanning, P.C. (2007): Exposure ages from mountain dipsticks in Mac. Robertson Land, 
East Antarctica, indicate little change in ice-sheet thickness since the Last Glacial Maximum. Geology, 35, 551-554.

Mackintosh, A., Golledge, N., Domack, E., Dunbar, R., Leventer, A., White, D., Pollard, D., DeConto, R., Fink, D., Zwartz, D., Gore, D. and Lavoie, C. (2011): Retreat of the East Antarctic ice sheet during the last glacial termination. Nature Geoscience, 4, 195-202.

Mackintosh, A.N., Verleyen, E., O’Brien, P.E., White, D.A., Jones, R.S., McKay, R., Dunbar, R. Gore, D.B., Fink, D., Post, A.L., Miura, H., Leventer, A., Goodwin, I., Hodgson, D.A., Lilly, L., Crosta, X., Golledge, N.R., Wagner, B., Bert, S., van Ommen, T., Zwartz, D., Roberts, S.J., Vyverman, W. and Masse, G. (2014) : Retreat history of the East Antarctic Ice Sheet since the Last Glacial Maximum. Quaternary Science Reviews, 100, 10-30.

Maemoku, H., Miura, H., Saigusa, S. and Moriwaki, K. (1997): Stratigraphy of the Late Quaternary raised beach deposits in the northern part of Langhovde, Lützow-Holm Bay, East Antarctica. Proceedings of NIPR Symposium, Antarctic Geoscience, 10, 178-186.

Martin-Español, A., Bamber, J.L. and Zammit-Mangion, A. (2017): Constraining the mass balance of East Antarctica. Geophysical Research Letters, 44, 4168-4175.

Matsuoka, K., Skoglund, A. and Roth, G. (2018): Quantarctica [Data set]. Norwegian Polar Institute, doi:10.21334/npolar.2018.8516e961.

Matsuoka, N., Thomachot, C.E., Oguchi, C.T., Hatta, T., Abe, M. and Matsuzaki, H. (2006): Quaternary bedrock erosion and landscape evolution in the Sør Rondane Mountains, East Antarctica: Reevaluating rates and processes. Geomorphology, 81, 408420.

Miller, K.G., Wright, J.D., Browning, J.V, Kulpecz, A., Kominz, M., Naish, T.R., Cramer, B.S., Rosenthal, Y., Peltier, R. and Sosdian, S. (2012): High tide of the warm pliocene: Implications of global sea level for Antarctic deglaciation. Geology, 40, 407-410.

三浦英樹 (2002) : 第四紀の南極水床変動と古海洋 - 古 気候変動. 月刊地球, 24, 3-7. [Miura, H. (2002): Antarctic ice sheet variability coupled with paleoceanographic and paleoclimatic changes during Quaternary. Chikyu Monthly (Gekkan Chikyu), 24, 3-7. (in Japanese)*]

三浦英樹 (2018)：最終水期最盛期以降の南極水床融 皮史：地形地質学から見た現状と課題. 低温科学,

76, 227-241. [Miura, H. (2018): Geomorphological and geological reconstruction of Antarctic Ice Sheet deglaciation since the Last Glacial Maximum: The current situation and future challenges. Low Temperature Science (Teion Kagaku), 76, 227241. (in Japanese with English abstract) ]

Miura, H., Maemoku, H., Igarashi, A. and Moriwaki,
K. (1998a): Late Quaternary raised beach deposits and radiocarbon dates of marine fossils around Lützow-Holm Bay. Special Map Series of National Institute of Polar Research, 6, National Institute of Polar Research.

Miura, H., Maemoku, H., Seto, K. and Moriwaki, K. (1998b): Late Quaternary East Antarctic melting event in the Soya Coast region based on stratigraphy and oxygen isotopic ratio of fossil molluscs. Polar Geoscience, 11, 260-274.

Miura, H., Moriwaki, K., Maemoku, H. and Hirakawa, K. (1998c): Fluctuations of the East Antarctic icesheet margin since the last glaciation from the stratigraphy of raised beach deposits along the Soya Coast. Annals of Glaciology, 27, 297-301.

三浦英樹・前圭英明 - 瀬戸浩二・五十嵐厚夫 (2002a) : リュツォ・ホルム湾周辺の隆起海浜堆積物から見 た第四紀後期の南極水床変動と古環境. 月刊地球,

24, 37-43. [Miura, H., Maemoku, H., Seto, K. and Igarashi, A. (2002a): Antarctic ice sheet variability coupled with paleoceanographic and paleoclimatic changes during Quaternary. Chikyu Monthly (Gekkan Chikyu), 24, 37-43. (in Japanese)*]

三浦英樹・前圭英明・吉永秀一郎・高田将志・Daniel Zwartz (2002b): 南極沿岸地域の完新世のイベント 一隆起海浜地形と放棄されたペンギンルッカリー一.

月刊地球，24，23-30. [Miura, H., Maemoku, H., Yoshinaga, S., Takada, M. and Zwartz, D. (2002b): Holocene event observed in Antarctic coast: Geomorphology of raised beach sediments and abandoned penguin rookeries. Chikyu Monthly (Gekkan Chikyu), 24, 23-30. (in Japanese)*]

Moriwaki, K., Hirakawa, K., Hayashi, M. and Iwata, S. (1992): Late Cenozoic glacial history in the SørRondane Mountains, East Antarctica. in Recent Progress in Antarctic Earth Science edited by Yoshida, Y., Kaminuma, K. and Shiraishi, K., Terra Scientific Publishing Company, 661-667.

Nakada, M. and Lambeck, K. (1987): Glacial rebound and relative sea-level variations: A new appraisal. Geophysical Journal of the Royal Astronomical Society, 90, 171-224.

Nakada, M. and Lambeck, K. (1988): The melting history of the late Pleistocene Antarctic ice sheet. Nature, 333, 36-40.

Nakada, M. and Lambeck, K. (1989): Late Pleistocene and Holocene sea-level change in the Australian region and mantle rheology. Geophysical Journal, 96, 497-517.

Nakada, M., Kimura, R., Okuno, J., Moriwaki, K., Miura, H. and Maemoku, H. (2000): Late Pleistocene and Holocene melting history of the Antarctic ice sheet derived from sea-level variations. Marine Geology, 167, 85-103.

Nakayama, Y., Menemenlis, D., Zhang, H., Schodlok, M. and Rignot, E. (2018): Origin of Circumpolar Deep Water intruding onto the Amundsen and 
Bellingshausen Sea continental shelves. Nature Communications, 9, 3430.

NASA's Goddard Space Flight Center (2017): Antarctic Ice Loss 2002-2016.

https://svs.gsfc.nasa.gov/30880 [Cited 2019/7/19].

大島慶一郎 (2018): 南極沿岸ポリニヤでの海水生成 と底層水形成. 低温科学, 76, 13-23. [Ohshima, K.I. (2018): Sea-ice production in Antarctic coastal polynyas and bottom water formation. Low Temperature Science (Teion Kagaku), 76, 13-23. (in Japanese with English abstract) ]

奥野淳一 (2018): 南極水床変動と水河性地殼均衡. 低 温科学, 76, 205-225. [Okuno, J. (2018): Antarctic ice sheet variation and Glacial Isostatic Adjustment. Low Temperature Science (Teion Kagaku), 76, 205-225. (in Japanese with English abstract) ]

Okuno, J. and Miura, H. (2013): Last deglacial relative sea level variations in Antarctica derived from glacial isostatic adjustment modelling. Geoscience Frontiers, 4, 623-632.

Pagani, M., Liu, Z., LaRiviere, J. and Ravelo, A.C. (2010): High Earth-system climate sensitivity determined from Pliocene carbon dioxide concentrations. Nature Geoscience, 3, 27-30.

Paolo, F.S., Fricker, H.A. and Padman, L. (2015): Volume loss from Antarctic ice shelves is accelerating. Science, 348, 327-331.

Pattyn, F. (2018): The paradigm shift in Antarctic ice sheet modelling. Nature Communications, 9, 1-3.

Pattyn, F., Ritz, C., Hanna, E., Asay-Davis, X., DeConto, R., Durand, G., Favier, L., Fettweis, X., Goelzer, H., Golledge, N.R., Munneke, P.K., Lenaerts, J.T.M., Nowicki, S., Payne, A.J., Robinson, A., Seroussi, H., Trusel, L.D. and van den Broeke, M. (2018): The Greenland and Antarctic ice sheets under $1.5^{\circ} \mathrm{C}$ global warming. Nature Climate Change, 8, 1053-1061.

Peltier, W.R. (2004): Global glacial isostasy and the surface of the ice-age Earth: The ICE-5G (VM2) Model and GRACE. Annual Review of Earth and Planetary Sciences, 32, 111-149.

Phartiyal, B., Sharma, A. and Bera, S.K. (2011): Glacial lakes and geomorphological evolution of Schirmacher Oasis, East Antarctica, during Late Quaternary. Quaternary International, 235, 128136.

Pritchard, H.D., Ligtenberg, S.R.M., Fricker, H.A., Vaughan, D.G., van den Broeke, M.R. and Padman, L. (2012): Antarctic ice-sheet loss driven by basal melting of ice shelves. Nature, 484, 502-505.

Rignot, E., Mouginot, J. and Scheuchl, B. (2011): Ice flow of the antarctic ice sheet. Science, 333, 14271430.

Rignot, E., Mouginot, J., Scheuchl, B., van den Broeke, M., van Wessem, M.J. and Morlighem, M. (2019): Four decades of Antarctic Ice Sheet mass balance from 1979-2017. Proceedings of the National Acad- emy of Sciences, 116, 1095-1103.

Seki, O., Foster, G.L., Schmidt, D.N., Mackensen, A., Kawamura, K. and Pancost, R.D. (2010): Alkenone and boron-based Pliocene $\mathrm{pCO}_{2}$ records. Earth and Planetary Science Letters, 292, 201-211.

Shepherd, A. and 46 others (2012): A reconciled estimate of ice-sheet mass balance. Science, 338, 11831189.

Shepherd, A. and 79 others (2018): Mass balance of the Antarctic Ice Sheet from 1992 to 2017. Nature, 558, 219-222.

Sjunneskog, C., Scherer, R., Aldahan, A. and Possnert, G. (2007): ${ }^{10}$ Be in glacial marine sediment of the Ross Sea, Antarctica, a potential tracer of depositional environment and sediment chronology. Nuclear Instruments and Methods in Physics Research $B$, 259, 576-583.

Stocchi, P., Colleoni, F. and Spada, G. (2009): Bounds on the time-history and Holocene mass budget of Anarctica from sea-level records in SE Tunisia. Pure and Applied Geophysics, 166, 1319-1341.

Suganuma, Y., Miura, H., Zondervan, A. and Okuno, J. (2014): East Antarctic deglaciation and the link to global cooling during the Quaternary: Evidence from glacial geomorphology and ${ }^{10} \mathrm{Be}$ surface exposure dating of the Sør Rondane Mountains, Dronning Maud Land. Quaternary Science Reviews, 97, 102-120.

菅沼悠介 ·田邊優貴子 · 香月興太 · 柴田大輔 - 川又基人 (2018): 水上からの湖底・海底堆積物掘削プロジェ クトの報告 (JARE-58/59). 南極資料，62，15-42.

[Suganuma, Y., Tanabe, Y., Katsuki, K., Shibata, D. and Kawamata, M. (2018): Report on lake/marine sediment coring from ice surface (JARE-58/59). Antarctic Record (Nankyoku Shiryo), 62, 15-42. (in Japanese with English abstract)]

菅沼悠介 - 香月興太 - 金田平太郎 - 川又基人 · 田邊優 貴子・柴田大輔 (2019): 可搬型パーカッションピス トンコアラーの開発. 地質学雑誌， 125，323-326.

[Suganuma, Y., Katsuki, K. Kaneda, H., Kawamata, M., Tanabe, Y. and Shibata, D. (2019): Portable percussion piston corer, lake sediments, shallow marine sediment. Journal of the Geological Society of Japan, 125, 323-326. (in Japanese with English abstract) ]

杉山 慎 (2018): 南極水床一その変動と海洋との相互 作用一。低温科学, 76, 169-177. [Sugiyama, S. (2018): The Antarctic ice sheet-Its variation and interaction with ocean-. Low Temperature Science (Teion Kagaku), 76, 169-177. (in Japanese with English abstract) ]

Takada, M., Tani, A., Miura, H., Moriwaki, K. and Nagatomo, T. (2003): ESR dating of fossil shells in the Lützow-Holm Bay region, East Antarctica. Quaternary Science Reviews, 22, 1323-1328.

Takano, Y., Tyler, J.J., Kojima, H., Yokoyama, Y., Tanabe, Y., Sato, T., Ogawa, N.O., Ohkouchi, H. and 
Fukui, M. (2012): Holocene lake development and glacial-isostatic uplift at Lake Skallen and Lake Oyako, Lützow-Holm Bay, East Antarctica: Based on biogeochemical facies and molecular signatures. Applied Geochemistry, 27, 2546-2559.

Vaughan, D.G., Comiso, J.C., Allison, I., Carrasco, J., Kaser, G., Kwok, R., Mote, P., Murray, T., Paul, F., Ren, J., Rignot, E., Solomina, O., Steffen, K. and Zhang, T. (2013): Observations: Cryosphere. in Climate Change 2013: The Physical Science Basis edited by Stocker, T.F., Qin, D., Plattner, G.-K., Tignor, M.M.B., Allen, S.K., Boschung, J., Nauels, A., Xia, Y., Bex, V. and Midgley, P.M., Cambridge University Pres, 317-382.

Verleyen, E., Hodgson, D.A., Sabbe, K., Vanhoutte, K. and Vyverman, W. (2004): Coastal oceanographic conditions in the Prydz Bay region (East Antarctica) during the Holocene recorded in an isolation basin. Holocene, 14, 246-257.

Verleyen, E., Hodgson, D.A., Milne, G.A., Sabbe, K. and Vyverman, W. (2005): Relative sea level history from the Lambert Glacier region (East Antarctica) and its relation to deglaciation and Holocene glacier re-advance. Quaternary Research, 63, 4552.

Verleyen, E., Tavernier, I., Hodgson, D.A., Whitehouse, P.L., Kudoh, S., Imura, S., Heirman, K., Bentley, M.J., Roberts, S.J., De Batist, M., Sabbe, K. and Vyverman, W. (2017): Ice sheet retreat and glacio-isostatic adjustment in Lützow-Holm Bay, East Antarctica. Quaternary Science Reviews, 169, 85-98.

Watcham, E.P., Bentley, M.J., Hodgson, D.A., Roberts, S.J., Fretwell, P.T., Lloyd, J.M., Larter, R.D., Whitehouse, P.L., Lengm, M.J., Monien, P. and Moreton, S.G. (2011): A new Holocene relative sea level curve for the South Shetland Islands, Antarctica. Quaternary Science Reviews, 30, 3152-3170.

White, D.A. and Fink, D. (2014): Late Quaternary glacial history constrains glacio-isostatic rebound in Enderby Land, East Antarctica. Journal of Geophysical Research, 119, 401-413.

White, D.A., Fink, D. and Gore, D.B. (2011) : Cosmogenic nuclide evidence for enhanced sensitivity of an East Antarctic ice stream to change during the last deglaciation. Geology, 39, 23-26.

White, D.A., Fink, D., Post, A.L., Simon, K., GaltonFenzi, B., Foster, S., Fujioka, T., Jeromson, M.R., Blaxella, M. and Yokoyama, Y. (2019): Beryllium isotope signatures of ice shelves and sub-ice shelf circulation. Earth and Planetary Science Letters, 505, 86-95.

Whitehouse, P.L., Bentley, M.J. and Le Brocq, A.M. (2012): A deglacial model for Antarctica: Geological constraints and glaciological modelling as a basis for a new model of Antarctic glacial isostatic adjustment. Quaternary Science Reviews, 32, 1-24.

Yamane, M., Yokoyama, Y., Miura, H., Maemoku, H., Iwasaki, S. and Matsuzaki, H. (2011): The last deglacial history of Lützow-Holm Bay, East Antarctica. Journal of Quaternary Science, 26, 3-6.

Yamasaki, S., Tabusa, T., Iwasaki, S. and Hiramatsu, M. (2017): Acoustic water bottom investigation with a remotely operated watercraft survey system. Progress in Earth and Planetary Science, 4, 25.

横山祐典 (2002): 最終水期のグローバルな水床量変動 と人類の移動. 地学雑誌, 111, 883-899. [Yokoyama, Y. (2002): Global ice volume during the Last Glacial and human migrations. Journal of Geography (Chigaku Zasshi), 111, 883-899. (in Japanese with English abstract) ]

Yokoyama, Y., Anderson, J.B., Yamane, M., Simkins, L.M., Miyairi, Y., Yamazaki, T., Koizumi, M., Suga, H., Kusahara, K., Prothro, L. and Hasumi, H. (2016): Widespread collapse of the Ross Ice Shelf during the late Holocene. Proceedings of the $\mathrm{Na}$ tional Academy of Sciences, 113, 2354-2359.

Yoshida, Y. (1983): Physiography of the Prince Olav and the Prince Harald Coasts, East Antarctica. Memoirs of National Institute of Polar Research. Ser. C, Earth Sciences, 13, 1-83.

Yoshida, Y. and Moriwaki, K. (1979): Some consideration on elevated coastal features and their dates around Syowa Station, Antarctica. Memoirs of $\mathrm{Na}$ tional Institute of Polar Research, Special Issue, 13, 220-226.

Zwally, H.J., Li, J., Robbins, J.W., Saba, J.L., Yi, D. and Brenner, A.C. (2015): Mass gains of the Antarctic ice sheet exceed losses. Journal of Glaciology, 61, 1019-1036.

Zwartz, D.P., Miura, H., Takada, M. and Moriwaki, K. (1998a): Holocene lake sediments and sea-level change at Mt. Riiser-Larsen. Polar Geoscience, 11, 249-259.

Zwartz, D., Bird, M., Stone, J. and Lambeck, K. (1998b): Holocene sea-level change and ice-sheet history in the Vestfold Hills, East Antarctica. Earth Planetary Science Letters, 155, 131-145. 